\title{
1 The Immune Signatures Data Resource: A compendium of systems 2 vaccinology datasets
}

Joann Diray-Arce ${ }^{1,2, *}$, Helen E.R. Miller ${ }^{2 *}$, Evan Henrich ${ }^{2, *}$, Bram Gerritsen ${ }^{3}$, Matthew P. Mulè $^{4,5}$, Slim Fourati ${ }^{6}$, Jeremy Gygi ${ }^{3}$, Thomas Hagan ${ }^{7}$, Lewis Tomalin ${ }^{8}$, Dmitry Rychkov ${ }^{9}$, Dmitri Kazmin ${ }^{10}$, Daniel G. Chawla ${ }^{3}$, Hailong Meng ${ }^{3}$, Patrick Dunn ${ }^{11}$, John Campbel1 ${ }^{11}$, The Human Immunology Project Consortium (HIPC) ${ }^{\&}$, Minnie Sarwal ${ }^{9}$, John S. Tsang ${ }^{4}$, Ofer Levy $^{1,2,12}$, Bali Pulendran ${ }^{7}$, Rafick Sekaly ${ }^{6}$, Aris Floratos ${ }^{13}$, Raphael Gottardo ${ }^{2,14}$, Steven H. Kleinstein $^{3, * *}$, Mayte Suárez-Fariñas ${ }^{8, * *}$

*These authors contributed equally

**These authors contributed equally

Affiliations:

${ }^{1}$ Precision Vaccines Program, Boston Children's Hospital, ${ }^{2}$ Harvard Medical School, Boston, MA, USA; ${ }^{2}$ Fred Hutchinson Cancer Research Center, Seattle, WA, USA; ${ }^{3}$ Yale School of

Medicine, New Haven, CT, USA; ${ }^{4}$ Multiscale Systems Biology Section, Laboratory of Immune System Biology, NIAID

NIH Center for Human Immunology, NIH, Bethesda, MD, USA; ${ }^{5}$ NIH-Oxford-Cambridge Scholars Program, Department of Medicine, Cambridge University; ${ }^{6}$ Emory University School of Medicine, Atlanta, GA, USA; ${ }^{7}$ Stanford University School of Medicine, Stanford University, Stanford, CA, USA; ${ }^{8}$ Icahn School of Medicine at Mount Sinai, New York, New York, USA; ${ }^{9}$ University of California, San Francisco, San Francisco, CA, USA; ${ }^{10}$ The Jackson Laboratory for Genomic Medicine, Farmington CT; ${ }^{11}$ ImmPort Curation Team, NG Health Solutions, Rockville, MD, USA; ${ }^{12}$ Broad Institute of MIT \& Harvard, Cambridge, MA, USA. ${ }^{13}$ Columbia University Medical Center, New York, NY, USA ${ }^{14}$ University of Lausanne and University Hospital of Lausanne, Lausanne, Switzerland 


\section{Abstract:}

Vaccines are among the most cost-effective public health interventions for preventing infection-induced morbidity and mortality, yet much remains to be learned regarding the mechanisms by which vaccines protect. Systems immunology combines traditional immunology with modern 'omic profiling techniques and computational modeling to promote rapid and transformative advances in vaccinology and vaccine discovery. The NIH/NIAID Human Immunology Project Consortium (HIPC) has leveraged systems immunology approaches to identify molecular signatures associated with the immunogenicity of many vaccines, including those targeting seasonal influenza, yellow fever, and hepatitis B. These data are made available to the broader scientific community through the ImmuneSpace data portal and analysis engine leveraging the NIH/NIAID ImmPort repository ${ }^{1,2}$. However, a barrier to progress in this area is that comparative analyses have been limited by the distributed nature of some data, potential batch effects across studies, and the absence of multiple relevant studies from non-HIPC groups in ImmPort. To support comparative analyses across different vaccines, we have created the Immune Signatures Data Resource, a compendium of standardized systems vaccinology datasets. This data resource is available through ImmuneSpace, along with code to reproduce the processing and batch normalization starting from the underlying study data in ImmPort and the Gene Expression Omnibus (GEO). The current release comprises 1405 participants from 53 cohorts profiling the response to 24 different vaccines and includes transcriptional profiles and antibody response measurements. This novel systems vaccinology data release represents a valuable resource for comparative and meta-analyses that will accelerate our understanding of mechanisms underlying vaccine responses.

\begin{tabular}{|c|c|c|}
\hline Design Type(s) & $\begin{array}{l}\text { ? } \\
\text { 酦 } \\
\text { ? }\end{array}$ & $\begin{array}{l}\text { Factorial design } \\
\text { Longitudinal design } \\
\text { Transcription profiling design }\end{array}$ \\
\hline Factor Type(s) & $\begin{array}{l}\text { ? } \\
\text { ? } \\
\text { ? } \\
\text { ? }\end{array}$ & $\begin{array}{l}\text { Sample type (PBMC, Blood) } \\
\text { Vaccine } \\
\text { Pathogen } \\
\text { Age groups }\end{array}$ \\
\hline Measurement Type(s) & $\begin{array}{l}\text { ? } \\
\text { ? } \\
\text { 目 } \\
\text { 目 }\end{array}$ & $\begin{array}{l}\text { Transcription profiling assay } \\
\text { Neutralizing antibody assay } \\
\text { ELISA } \\
\text { Influenza hemagglutination inhibition } \\
\text { assay (HAI) }\end{array}$ \\
\hline Technology Type(s) & $\begin{array}{l}\text { ? } \\
\text { 圆 } \\
\end{array}$ & $\begin{array}{l}\text { Microarray } \\
\text { RNA sequencing }\end{array}$ \\
\hline Sample Characteristic(s) & ? & Homo sapiens \\
\hline
\end{tabular}




\section{Background and Summary}

73 Vaccines, one of humanity's greatest public health achievements, save millions of lives every year by

74 preventing infectious diseases ${ }^{3,4}$. Despite their widespread use and efficacy, much remains to be learned

75 regarding their molecular mechanisms of action. This is true both for vaccines against pandemic

76 infections such as influenza ${ }^{5}$, and SARS-coronavirus $-2^{6}$, as well as for infections for which there are

77 currently no authorized or approved vaccines such as $\mathrm{HIV}^{7-9}$. Elucidating the commonalities and

78 differences in the immune responses induced by different vaccines and their association with protective

79 antibody responses will provide deeper insight and a framework for the evidence-based design of better

80 vaccines or vaccination strategies. Recent technologies have provided tools to probe the immune response

81 to vaccination and integrate hierarchical levels of the biological system ${ }^{10}$. Alluded to as systems

82 vaccinology ${ }^{11}$, this new application of systems biology tools provides new insights into molecular

83 mechanisms of vaccine-induced immunogenicity and protection ${ }^{12-15}$.

84 The National Institute of Allergy and Infectious Diseases (NIAID) established a multi-

85 institutional consortium, Human Immunology Project Consortium (HIPC) $)^{2,16}$, to characterize the immune

86 system in diverse populations in response to a stimulus, such as vaccination, using high-dimensional

87 'omic platforms and modern computational tools ${ }^{2}$. Since the inception of the consortium in 2010,

88 members of HIPC have published > 500 articles, including many that describe molecular signatures

89 associated with vaccine-induced protection. These studies include molecular signatures that predict the

90 immunogenicity of vaccination against yellow fever ${ }^{17-20}$, seasonal influenza in healthy young adults,

91 elderly $^{21-25}$, and children ${ }^{26}$, shingles ${ }^{27,28}$, dengue ${ }^{29,30}$, malaria ${ }^{31,32}$, and meta-analyses of common signatures

92 across different vaccines ${ }^{33,34}$. These molecular signatures resulted from large-scale data analysis using

93 high-throughput systems biology approaches coupled with detailed clinical phenotyping in well-

94 characterized human cohorts.

95 Predicting immunogenicity from 'omic signatures remains challenging, prompting

96 methodological innovation to advance the field towards delivering on the promises of precision

97 vaccination ${ }^{35-37}$. The factors that contribute to robust vaccination responses are highly complex and span

98 multiple biological scales. The vast collection of high-dimensional profiling datasets poses significant

99 challenges for comparative analysis of these studies, including biological variability as well as data

100 challenges such as volume, technical noise, and diverse sample processing pipelines. Data integration of

101 cellular and molecular signatures to predict vaccine responses requires harmonization and normalization

102 of data from multiple sources ${ }^{38}$. The generation of big data poses simultaneous challenges and

103 opportunities with the potential of contributing to precision medicine. The biological interpretation of the

104 resulting molecular features correlated with robust responses is another key factor. Understanding how

105 effective vaccines stimulate protective immune responses, and how these mechanisms may differ between 
vaccine types and targeted pathogens remains a substantial challenge for the field. Moreover, the systems vaccinology field has been limited by a lack of a formal framework to standardize immune signatures

108 gathered from diverse studies, creating a bottleneck for comparative analysis. To address these 109 challenges, and in support of advances in systems vaccinology by the HIPC project and the broader 110 scientific community, we present the creation of the Immune Signatures Data Resource, a compendium of 111 systems vaccinology studies that enables standardized comparative analysis to identify molecular 112 signatures that correlate with the outcomes of vaccinations.

113 The current release of the Immune Signatures Data Resource consists of 4795 transcriptomic 114 samples from 1405 participants curated from 30 ImmPort studies (16 from HIPC-related studies, 14 non115 HIPC studies) (Figure 2). The transcriptomic profiling dataset is derived from 53 cohorts of 820 young 116 adults (18-49 years old) and 585 ( $\geq 50$ years old) older adult samples. The data resource covers 24 117 vaccines targeting 11 pathogens and 6 vaccine types (Figure 1B, 4A), thus creating a critical mass of data 118 that will serve as a valuable resource for the broader scientific community. Additionally, data assembly 119 and integration of these data set enables derivation of comparable signatures for each study for 120 comparative analysis of the underlying data.

\section{Methods:}

\section{Database background information and structure}

124 Compatibility with ImmPort and ImmuneSpace, the central databases of the Human Immunology

125 Project Consortium: Given the exponential growth of the number of datasets of multiple modalities, an 126 urgent need emerged for data sharing across the broader scientific community. The HIPC implements the 127 NIH Data Sharing policy to promote the principles of Findability, Accessibility, Interoperability, and 128 Reusability (FAIR) via ImmPort, created under the National Institute of Allergy and Infectious Diseases 129 Division of Allergy, Immunology, and Transplantation (NIAID-DAIT). ImmPort (ImmPort.org) is an 130 open repository of participant-level large-scale human immunology data designed to aid scientists with 131 data standards and guidelines for efficient secondary analyses ${ }^{1,39}$. ImmPort facilitates data sharing of 132 immunology studies creating a centralized knowledge base and resources, and serves as a central data 133 repository for HIPC. ImmuneSpace ${ }^{2,34}$ extends ImmPort, providing access to additional data (e.g., 134 standardized gene expression matrices) and web-based $\mathrm{R}$ tools for data accession, analysis, and reporting. 135 Studies in the Immune Signatures Data Resource are archived through the Shared Data Portal on ImmPort 136 and ImmuneSpace repositories and may be updated over time. To provide a consistent data source for 137 reproducible results, we also archived a static copy of the data as a "virtual study" in ImmuneSpace 138 (Figure 1A \& 2). 
Identification of vaccine study cohorts with transcriptomic profiles: Through a literature search

140 conducted from 2017 to 2020, we identified target publications with systems-level profiling of human

141 vaccination responses. We found 16 HIPC-funded vaccinology studies in ImmPort with transcriptomics

142 datasets generated with matching immune response outcomes. Notably, we have supplemented the HIPC

143 data previously available in ImmPort by curating and submitting 14 additional human vaccination studies

144 to ImmPort. For studies that were not in ImmPort/ImmuneSpace, we located the underlying data by

145 surveying public transcriptome databases (e.g., Gene Expression Omnibus (GEO)) or reaching out to

146 study authors to request data access, allowing us to submit to ImmPort on their behalf. These datasets

147 were then made available via ImmuneSpace to be processed for standardization, preprocessing checks,

148 and normalization. The standard analytical pipeline enables reproducibility and comparability of future

149 studies to be correlated with publicly available immune response measurement. This process created the

150 virtual study for the HIPC named the Immune Signatures Data Resource (Figure 1A, Figure 2).

\section{Gene Expression Data processing pipeline}

152 Data were read directly from ImmuneSpace using ImmuneSpaceR functions and subsequently

153 preprocessed, quality controlled, and integrated using the following pipeline:

154 Quality Control of Microarray experiments: The ArrayQualityMetrics R package ${ }^{40}$ was used for quality

155 control and assurance of all microarray experiments (Figure 3A). Outlier detection was based on the

156 following statistics: i) Mean absolute difference of M-values (log-ratios) of each pair of arrays, ii) the

157 Kolmogorov-Smirnov statistic $K_{a}$ between each array's signal intensity distribution and the distribution of

158 the pooled data and, iii) the Hoeffding's statistic $D_{a}$ on the joint distribution of A (average) and M values

159 for each array. Using pre-specified criteria within an established public microarray data reuse pipeline ${ }^{40}$,

160 we flagged for removal arrays that failed all three quality control statistics.

161 Preprocessing: Raw probe intensity data for Affymetrix studies were background-corrected and 162 summarized using the RMA algorithm ${ }^{41}$ while the function read.ilmn (limma $\mathrm{R}$ package) was used to read 163 and background correct Illumina raw probe intensities. To integrate RNA-seq and microarray data, raw 164 counts for RNA-seq data were converted to log-transformed values incorporating observational level 165 weights to account for technical variations using the $v o o m^{42}$ transformation. Expression data within each 166 study were quantile normalized and log-transformed separately for each cohort/sample type.

167 Annotation: We annotated the manufacturing IDs (probes from microarray/Illumina) to their 168 corresponding gene alias. Gene aliases were mapped to the recent gene symbols from the HUGO Gene 169 Nomenclature Committee ${ }^{43}$ [accessed Dec 23, 2020]. For the rare case where a gene alias mapped to more 170 than one gene symbol, the mapping was resolved by the following: i) If a gene alias mapped to itself as a 171 symbol, as well as other symbols, then it was mapped to itself; ii) if the gene alias mapped to multiple 
172 symbols that did not include itself, then the gene alias was dropped from the study. As a result, the raw

173 gene expression matrix was reduced to 10086 HUGO gene aliases with known unique mapping.

174 Gene-based expression profiles: Expression data were summarized at the probe level (for microarray 175 data) and gene-alias level (RNA-seq) to the canonical Gene-Symbol level. The probes / gene-aliases were 176 summarized by selecting the probe or gene-alias with the highest average expression (mean of probes 177 across all samples, take the highest mean) across all samples within the matrix (cohort and sample type).

178 Cross-Study normalization: One of the main assumptions in expression analysis is that differences in 179 gene expression across conditions occur in a relatively small number of processes. As such, the 180 distribution across conditions should be similar, and departures of these assumptions are corrected, for 181 example, using quantile normalization. This procedure usually creates a target distribution using all 182 samples available, but we observed dissimilar distributions in our collection stemming from various 183 platforms used. Such differences lead to extensive distributions and introduce artifacts in the data (Figure 184 3B and 3C). The target distribution was obtained from samples using Affymetrix platforms, resulting in a 185 well-defined distribution, and each sample in our collection was quantile normalized to this target 186 distribution. Before cross-study normalization, there were 35,725 representative gene symbols present. 187 There were 25,639 genes removed after normalization, as these genes were not present in all the studies. 188 This yielded a final expression matrix of 4795 samples from 1405 participants representing 10,086 genes 189 (Figure 2).

190 Determining and adjusting for technical confounders: We studied the primary sources of variation in 191 the data, including the study effect (which also encompasses the impact of different expression platforms 192 (RNA-seq, Affymetrix arrays, Illumina arrays, etc.), sample types (Whole blood, PBMC), as well as 193 demographics. We conducted Principal Component Analysis (PCA) to visualize such associations in a 194 bidimensional space of principal components (PCs) and applied Principal Variance Component Analysis

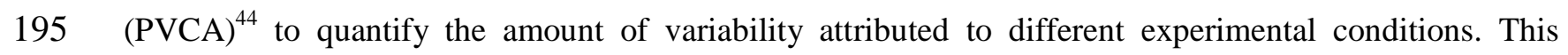
196 approach models the multivariate distribution of the PCs computed for the PCA as a function of 197 experimental factors and estimates the total variance explained by each factor via mixed-effect models. 198 Since many studies included only one vaccine, temporal variations due to vaccine response were 199 confounded with the study effect. The assessment of the primary technical sources of variation was 200 carried out using only the pre-vaccination data, not affected by the targeted pathogen and vaccine type 201 used in the different studies. Of note, all studies enrolled healthy volunteers, and the first biosample was 202 obtained pre-vaccination. The targeted pathogen and vaccine type should not affect these baseline data.

203 Platform, study, and sample types were identified as significant sources of variation in the gene 204 expression matrix. The effect of those three variables was estimated by modeling gene expression at 205 baseline (at which no vaccine or timepoint effect exists) with a linear model using the limma framework, 
206 including feature set vendor (Platform/Affy), study (batch factors), and sample type, Y-chromosome 207 genes presence, as covariates. Study and cell-type effects were estimated using a linear model with age, 208 Y-chromosome genes presence (biological sex), study, sample type (Whole Blood/PBMC), study, and 209 platform as additive effects. From here, the study, platform, and cell-type effects were eliminated from 210 the entirety of the expression matrix. There were three studies (SDY1276, SDY1264, SDY180) that 211 contained multiple cohorts and were treated as separate studies.

212 Biological sex imputation: Imputation of biological sex, as defined by the presence of a Y-chromosome, 213 was carried out based on the gene expression profiles of 13 Y-chromosome genes. Within each study, a 214 multidimensional scaling was first applied to the Y-chromosome gene expression profiles. K-means 215 clustering was then used to cluster samples into two groups. Participants in the cluster with higher mean 216 expression values were considered male (i.e., the Y-chromosome was present) while those in the cluster 217 with lower expression were considered female (i.e., the Y-chromosome was absent). The consistency of 218 the Y-chromosome presence assignment across time points was verified (Figure 3D). In the (few) cases 219 where imputation was not in agreement across all time points, the reported sex was used and if no sex was 220 reported, imputation followed a majority rule principle.

221 Age Imputation: Age imputation for studies without reported ages (SDY1260, SDY1264, SDY1293, 222 SDY1294, SDY1364, SDY1370, SDY1373, SDY984) employed the RAPToR R v1.1.5 package ${ }^{45}$. The 223 RAPToR algorithm takes in a reference set of gene expression time series with reported ages and 224 generates a near-continuous, high-temporal resolution from the interpolated reference dataset. 225 Transcriptomic profiles of participants without reported ages were compared to the reference dataset via a 226 correlation profile, providing age estimates for the sample. Finally, random subsets of genes from the 227 subject's transcriptomic profile were bootstrapped to ascertain a confidence interval for the imputed age. 228 We generated the reference dataset using the transcriptomic profiles of 21 studies in our resource for 229 which age was reported. The studies were split into younger (age < 50) and older (age $\geq 50$ ) cohorts, thus 230 two different models were generated, and only baseline transcriptomic profiles were used in the reference 231 dataset. As RAPToR also enables phenotypic data to be incorporated into the interpolation model, each 232 possible combination of phenotypic features was tested. For each combination, RAPToR predicted the 233 age for participants in the 21 studies with known age, and the goodness of fit was evaluated by the 234 coefficient of determination $\left(\mathrm{R}^{2}\right)$. The best model for the younger and older cohorts was then used to 235 impute ages for the 7 studies without reported age (Figure 3E, 3F)

236 Immune response datasets processing pipeline:

237 To identify the molecular signatures that correlate with vaccine immunogenicity, we included immune 238 response readouts in the creation of this data resource. For studies that were missing vaccine response 239 endpoints in their public data deposition, we contacted study authors and requested available antibody 
240 response measures to vaccine antigens. Once shared, these data were submitted to ImmPort and linked to 241 the relevant studies. These readouts include neutralizing antibody titers (Nab), hemagglutination 242 inhibition assay (HAI) results for influenza studies, and Immunoglobulin IgG ELISA assay results. In 243 participants for whom the humoral immune response was measured with multiple assays, the preference 244 was given to HAI for influenza or Nab for non-influenza studies, then IgG ELISA datasets. The antibody 245 measures were normalized within each study by estimating the fold-change differences between the post246 vaccination time-point (generally between day 28 or day 30) compared to the baseline measurement. For 247 influenza studies where the vaccine included multiple strains, the fold changes between the post248 vaccination versus baseline were calculated for each strain, and the maximum fold change (MFC) over 249 the strains was selected ${ }^{34}$. Due to the variability in baseline antibody (Ab) levels and immune memory 250 such as influenza vaccines, we also estimated the maximum residual after baseline adjustment (maxRBA) 251 method by calculating the maximum residual across all vaccine strains to adjust for variable baseline $\mathrm{Ab}$ 252 levels using the $\mathrm{R}$ package titer $^{21}$. A total of 30 studies with 1405 participants and 4795 samples have 253 both transcriptomics and immune response readout data available (Figure 2). This dataset enables 254 researchers to carry out comparative analyses using immunogenicity data as well as prediction of the 255 quality of response across multiple vaccines.

Data Records:

258 The Immune Signatures Data Resource is available online for download by the research community from 259 this website: The data is hosted on ImmuneSpace and can be accessed via the R package ImmuneSpaceR 260 (https://rglab.github.io/ImmuneSpaceR/ ). The resource is available for use by the scientific community 261 and can be downloaded from a research data repository IS2 https://www.ImmuneSpace.org/is2.url. A 262 summary of datasets, with their corresponding study ID and accession numbers, is provided in Table 4.

\section{Technical Validation}

\section{Quality Control and Assurance}

266 For global quality control across all public microarray data, we used a well-established pipeline available 267 through the ArrayQualitymetrics $\mathrm{R}$ package ${ }^{40}$. Using pre-specified criteria established in the existing 268 public microarray data reuse pipeline ${ }^{46}$, arrays that failed 3 out of 3 calculated quality control statistics 269 were flagged for removal (see Methods). Consistent with standard practice to perform such quality 270 control analysis prior to downstream analysis and dataset submission to the Gene Expression Omnibus, 271 none of the samples were outliers by all three statistics (Fig 3A). As expected for data from published 272 peer-reviewed studies, all the identified studies passed the quality assurance method using the 273 Arrayqualitymetrics method. 


\section{Y-chromosomal presence and age imputation}

275 A few studies were missing information for sex and for age. To achieve data completeness, we included

276 the biological sex imputation based on the imputed presence of the Y-chromosome using gene expression,

277 as well as imputation of age when the variable was missing or defined by a broad range of values. Age

278 imputation employed the RAPToR tool using 21 studies with reported age to define the best predictive

279 model for the younger (age $<50$ years) and older (age $\geq 50$ years) cohorts separately. The highest

280 correlation coefficients from the young cohort were generated by taking into account the model (X

281 age_reported + matrix) with a correlation coefficient of $\mathrm{R}^{2}=0.367$ (Figure 3E), while the old cohort

282 yielded a prediction $\mathrm{R}^{2}$ of 0.536 for their highest coefficient value (Figure $3 \mathrm{~F}$ ).

\section{Definition of Vaccination Studies Transcriptomic Cohort}

284 Data preprocessing in ImmuneSpace yielded a total of 30 studies and 59 cohorts, with 1482 participants

285 and 5413 samples. After the data was preprocessed and quality control measures were performed, we

286 further assessed the identified cohorts as defined in the flow diagram (Figure 2). This curation included: i)

287 removing participants that were not relevant to the objective $(n=34)$; ii) removing samples due to

288 inconsistencies with time design determination $(\mathrm{n}=178)$; iii) removing participants with no baseline

289 expression data $(\mathrm{n}=42)$. Some studies, such as SDY1368 and SDY67, were dropped from the normalized

290 data sets as they did not include subjects within our target age range (18-50 years). In summary, we report

291 that the final Immune Signatures Data Resource contains 53 cohorts from 30 studies with 1405

292 participants and 4795 samples.

\section{Assessment and adjustment of the batch effects}

294 We evaluated the main sources of variation on the gene expression matrix to identify and adjust technical

295 confounders (RNA-seq, Affymetrix arrays, Illumina arrays, etc.), study, and specimen types (e.g., whole

296 blood vs. PBMCs) using the baseline samples. Since all studies enrolled healthy volunteers, and the first

297 sample was taken pre-vaccination, pathogen and vaccine type would not affect the baseline data. Figure

298 3B clearly demonstrates robust clustering of samples by study, which are also grouped by platform type.

299 The study effect and type of platform used accounted for the vast majority (95\%) of variation, followed

300 by specimen types (3.6\%). It is thus essential that the data are corrected for these major effects prior to

301 any analytical usage [see Materials and Methods for further details]. The study, platform type, and

302 specimen type-specific effects were estimated using a linear model that also included age and Y-

303 chromosome presence as additive effects using only baseline expression. Once the study, platform, and

304 specimen-type effects were estimated, they were eliminated from the entirety of the expression matrix.

305 Figure 3B shows that those effects can successfully be adjusted from the data, thus leading to a matrix of

306 expression that is free of most technical biases induced by the laboratory and cell-type effects.

307 Immune Signatures Transcriptomics and Immune Response Datasets 
We report the total number of assay samples collected from the transcriptomic and immune response datasets tallied by targeted pathogen and vaccine type, across multiple systems vaccinology datasets (Figure 4A). We captured about 3000 HAI antibody titer results from influenza studies that were measured by the standard HAI assay pre- and at multiple time points post-vaccination, depending on the study. Mean titers were calculated for the reported strains of the virus and were based on the highest dilution reported at day 28-30 post-vaccination. In addition, neutralizing antibody (NAB) titers and IgG

314 ELISA results specific to each pathogen were determined by each study and are summarized (Figure 4A).

315 The overall transcriptomics dataset comprises multiple time points from 7 days pre-vaccination up to day

316180 days post-vaccination (Figure 4B). While most of the datasets focus on the young adult population

317 (ages 18-50 years old), the data resource also includes studies that profile older adults following hepatitis

318 B, influenza, and varicella vaccination (Figure 4C) that may be useful for analysis. The Euler diagram

319 describes the dataset overlap of participants with transcriptomics datasets and corresponding to one or 320 more immune response datasets (Figure 4D).

321 Heterogeneity of the immune response to vaccination across targeted pathogens and vaccine types was 322 reflected in variation in the longitudinal trajectories of HAI and NAB titer measurements (Figure 5A and 323 5B). HAI and NAB titers generally increased by 14-28 days after vaccination but attenuated at different 324 times for each vaccine (Figure 5A and 5B). Change in NAB titers after vaccination were significantly 325 different across the 5 unique combinations of targeted pathogen and vaccine types where these 326 measurements were reported (ANOVA $\mathrm{p}<10^{-10}$ ), with significant differences across all 5 groups except 327 between meningococcus and yellow fever vaccines (Figure 5C). Some influenza vaccination studies 328 reported both HAI and NAB measures of immunogenicity, and there was a significant positive correlation 329 between the vaccination-induced changes in these titers across participants (Spearman's rho $=0.45, \mathrm{p}$ $330<10^{-10}$ ) (Figure 5D).

\section{Usage Notes}

333 The expression data and accompanying meta-data have been made available with different formats and 334 options to ease usage. Data are available as standard expression sets (eSet) objects, the R/Bioconductor 335 structure unifying expression values, metadata, and gene annotation. Both normalized data and batch336 adjusted data are available (Table 4). Users interested in a single study or those planning to work 337 exclusively within participants' changes may opt for the normalized data without batch adjustment. For 338 comparison of time points across studies or developing algorithms that use expression data, batch 339 corrected matrices should be employed. Imputed age values for participants with no reported age were

340 included to facilitate the use of age as a covariate in future analysis. Such analysis can be carried out with 341 the complete data set and can be followed up by a sensitivity analysis using the small cohort with age- 
342 reported data. For the use of expression sets with the corresponding immune response per participant,

343 these are available in eSets noted with a response. The selected immune response outcome per study is

344 also summarized in Table 3.

\section{Code Availability}

347 The source codes for the Immune Signatures Data Resource and all data are available in ImmuneSpace

348 (https://www.immunespace.org/is2.url). Pre-processing code and supplementary data can be found in the

349 ImmuneSignatures2 R package hosted on Github (https://github.com/RGLab/ImmuneSignatures2).

\section{Acknowledgments}

352 This research was conducted within the Human Immunology Project Consortium (HIPC) and supported

353 by the National Institute of Allergy and Infectious Diseases. This work was supported in part by NIH

354 grants U19AI128949, U19AI118608, U19AI1 18626, and U19AI089992, U19AI090023, U19AI089992,

355 U19AI128914, U19AI118610, U19AI128913. The HIPC projects are listed

356 at https://www.immuneprofiling.org/hipc/page/showPage?pg=projects. This work was supported in part by the Canadian Institutes of Health Research [funding reference number FDN-154287]

Contributions

360 All authors identified the datasets, performed quality control, and assurance and analyzed the datasets.

361 JD-A, HM, SHK and MSF led the writing and organization of the manuscript. HM, EH, PD, together with 362 the ImmuneSpace and ImmPort team, implemented the pipeline for data access and visualization. The 363 HIPC Consortium contributed to the conception and design of the work, as well as the acquisition of data.

364 A full list of the HIPC Consortium members can be found in Supplementary File 1. All authors edited and 365 approved the manuscript.

\section{Corresponding authors}

368 Please address correspondence to joann.arce@ childrens.harvard.edu or mayte.suarezfarinas@ mssm.edu.

370 Ethics declaration

371 S.H.K. receives consulting fees from Northrop Grumman and Peraton. OL is an inventor on several

372 patents relating to vaccine adjuvants and human in vitro systems predicting vaccine action. R.G. has

373 received consulting income from Illumina, Takeda, and declares ownership in Ozette Technologies and

374 Modulus Therapeutics. The other authors declare no competing interests. 


\section{REFERENCES:}

3761 Bhattacharya, S. et al. ImmPort, toward repurposing of open access immunological assay data for translational and clinical research. Sci Data 5, 180015, doi:10.1038/sdata.2018.15 (2018). Brusic, V., Gottardo, R., Kleinstein, S. H., Davis, M. M. \& committee, H. s. Computational resources for high-dimensional immune analysis from the Human Immunology Project Consortium. Nat Biotechnol 32, 146-148, doi:10.1038/nbt.2777 (2014).

3 Piot, P. et al. Immunization: vital progress, unfinished agenda. Nature 575, 119-129, doi:10.1038/s41586-019-1656-7 (2019).

4 Pulendran, B. Systems vaccinology: probing humanity's diverse immune systems with vaccines. Proc Natl Acad Sci U S A 111, 12300-12306, doi:10.1073/pnas.1400476111 (2014).

5 Fineberg, H. V. Pandemic preparedness and response--lessons from the H1N1 influenza of 2009. N Engl J Med 370, 1335-1342, doi:10.1056/NEJMra1208802 (2014). Fauci, A. S., Lane, H. C. \& Redfield, R. R. Covid-19 - Navigating the Uncharted. N Engl J Med, doi:10.1056/NEJMe2002387 (2020).

7 Fauci, A. S. An HIV Vaccine Is Essential for Ending the HIV/AIDS Pandemic. JAMA 318, 15351536, doi:10.1001/jama.2017.13505 (2017).

8 Fauci, A. S., Folkers, G. K. \& Marston, H. D. Ending the global HIV/AIDS pandemic: the critical role of an HIV vaccine. Clin Infect Dis 59 Suppl 2, S80-84, doi:10.1093/cid/ciu420 (2014).

9 Fauci, A. S. \& Marston, H. D. Ending the HIV-AIDS Pandemic--Follow the Science. N Engl J Med 373, 2197-2199, doi:10.1056/NEJMp1502020 (2015).

10 Diercks, A. \& Aderem, A. Systems approaches to dissecting immunity. Curr Top Microbiol Immunol 363, 1-19, doi:10.1007/82_2012_246 (2013).

11 Pulendran, B., Li, S. \& Nakaya, H. I. Systems Vaccinology. Immunity 33, 516-529, doi:http://dx.doi.org/10.1016/j.immuni.2010.10.006 (2010).

12 Tsang, J. S. et al. Improving Vaccine-Induced Immunity: Can Baseline Predict Outcome? Trends Immunol 41, 457-465, doi:10.1016/j.it.2020.04.001 (2020).

13 Nakaya, H. I., Li, S. \& Pulendran, B. Systems vaccinology: learning to compute the behavior of vaccine induced immunity. Wiley Interdiscip Rev Syst Biol Med 4, 193-205, doi:10.1002/wsbm.163 (2012).

14 Nakaya, H. I. \& Pulendran, B. Systems vaccinology: its promise and challenge for HIV vaccine development. Curr Opin HIV AIDS 7, 24-31, doi:10.1097/COH.0b013e32834dc37b (2012).

15 Zak, D. E. \& Aderem, A. Overcoming limitations in the systems vaccinology approach: a pathway for accelerated HIV vaccine development. Curr Opin HIV AIDS 7, 58-63, doi:10.1097/COH.0b013e32834ddd31 (2012).

16 Poland, G. A., Quill, H. \& Togias, A. Understanding the human immune system in the 21st century: the Human Immunology Project Consortium. Vaccine 31, 2911-2912, doi:10.1016/j.vaccine.2013.04.043 (2013).

17 Muyanja, E. et al. Immune activation alters cellular and humoral responses to yellow fever 17D vaccine. J Clin Invest 124, 3147-3158, doi:10.1172/JCI75429 (2014).

18 Gaucher, D. et al. Yellow fever vaccine induces integrated multilineage and polyfunctional immune responses. J Exp Med 205, 3119-3131, doi:10.1084/jem.20082292 (2008).

19 Querec, T. D. et al. Systems biology approach predicts immunogenicity of the yellow fever vaccine in humans. Nat Immunol 10, 116-125, doi:10.1038/ni.1688 (2009).

20 Querec, T. et al. Yellow fever vaccine YF-17D activates multiple dendritic cell subsets via TLR2, 7, 8, and 9 to stimulate polyvalent immunity. $J$ Exp Med 203, 413-424, doi:10.1084/jem.20051720 (2006).

21 Avey, S. et al. Seasonal Variability and Shared Molecular Signatures of Inactivated Influenza Vaccination in Young and Older Adults. J Immunol 204, 1661-1673, doi:10.4049/jimmunol.1900922 (2020). 
424

425

426

427

428

429

430

431

432

433

434

435

436

437

438

439

440

441

442

443

444

445

446

447

448

449

450

451

452

453

454

455

456

457

458

459

460

461

462

463

464

465

466

467

468

469

470

471

472

473

22 Nakaya, Helder I. et al. Systems Analysis of Immunity to Influenza Vaccination across Multiple Years and in Diverse Populations Reveals Shared Molecular Signatures. Immunity 43, 1186-1198, doi:http://dx.doi.org/10.1016/j.immuni.2015.11.012 (2015).

23 Nakaya, H. I. et al. Systems biology of vaccination for seasonal influenza in humans. Nat Immunol 12, 786-795, doi:10.1038/ni.2067 (2011).

24 Oh, Jason Z. et al. TLR5-Mediated Sensing of Gut Microbiota Is Necessary for Antibody Responses to Seasonal Influenza Vaccination. Immunity 41, 478-492, doi:http://dx.doi.org/10.1016/j.immuni.2014.08.009 (2014).

25 Thakar, J. et al. Aging-dependent alterations in gene expression and a mitochondrial signature of responsiveness to human influenza vaccination. Aging (Albany NY) 7, 38-52, doi:10.18632/aging.100720 (2015).

26 Nakaya, H. I. et al. Systems biology of immunity to MF59-adjuvanted versus nonadjuvanted trivalent seasonal influenza vaccines in early childhood. Proc Natl Acad Sci U S A 113, 18531858, doi:10.1073/pnas.1519690113 (2016).

27 Li, S. et al. Metabolic Phenotypes of Response to Vaccination in Humans. Cell 169, 862-877 e817, doi:10.1016/j.cell.2017.04.026 (2017).

28 Sullivan, N. L. et al. Breadth and Functionality of Varicella-Zoster Virus Glycoprotein-Specific Antibodies Identified after Zostavax Vaccination in Humans. J Virol 92, doi:10.1128/JVI.0026918 (2018).

29 Michlmayr, D. et al. Comprehensive Immunoprofiling of Pediatric Zika Reveals Key Role for Monocytes in the Acute Phase and No Effect of Prior Dengue Virus Infection. Cell Rep 31, 107569, doi:10.1016/j.celrep.2020.107569 (2020).

30 Katzelnick, L. C. et al. Antibody-dependent enhancement of severe dengue disease in humans. Science 358, 929-932, doi:10.1126/science.aan6836 (2017).

31 Kazmin, D. et al. Systems analysis of protective immune responses to RTS,S malaria vaccination in humans. Proc Natl Acad Sci U S A 114, 2425-2430, doi:10.1073/pnas.1621489114 (2017).

32 Mpina, M. et al. Controlled Human Malaria Infection Leads to Long-Lasting Changes in Innate and Innate-like Lymphocyte Populations. J Immunol 199, 107-118, doi:10.4049/jimmunol.1601989 (2017).

33 Li, S. et al. Molecular signatures of antibody responses derived from a systems biology study of five human vaccines. Nat Immunol 15, 195-204, doi:10.1038/ni.2789 (2014).

34 Team, H.-C. S. P. \& Consortium, H.-I. Multicohort analysis reveals baseline transcriptional predictors of influenza vaccination responses. Sci Immunol 2, doi:10.1126/sciimmunol.aal4656 (2017).

35 Azuaje, F. Computational models for predicting drug responses in cancer research. Brief Bioinform 18, 820-829, doi:10.1093/bib/bbw065 (2017).

36 Jia, S., Li, J., Liu, Y. \& Zhu, F. Precision immunization: a new trend in human vaccination. Hum Vaccin Immunother 16, 513-522, doi:10.1080/21645515.2019.1670123 (2020).

37 Gao, A. et al. Predicting the Immunogenicity of T cell epitopes: From HIV to SARS-CoV-2. bioRxiv, doi:10.1101/2020.05.14.095885 (2020).

38 Chaussabel, D. Assessment of immune status using blood transcriptomics and potential implications for global health. Semin Immunol 27, 58-66, doi:10.1016/j.smim.2015.03.002 (2015).

39 Bhattacharya, S. et al. ImmPort: disseminating data to the public for the future of immunology. Immunol Res 58, 234-239, doi:10.1007/s12026-014-8516-1 (2014).

40 Kauffmann, A., Gentleman, R. \& Huber, W. arrayQualityMetrics--a bioconductor package for quality assessment of microarray data. Bioinformatics 25, 415-416, doi:10.1093/bioinformatics/btn647 (2009).

41 Irizarry, R. A. et al. Exploration, normalization, and summaries of high density oligonucleotide array probe level data. Biostatistics 4, 249-264, doi:10.1093/biostatistics/4.2.249 (2003). 
474

475

476

477

478

479

480

481

482

483

484

485

486

487

488

489

490

491

492

493

494

495

496

497

498

499

500

501

502

503

504

505

506

507

508

509

510
42 Law, C. W., Chen, Y., Shi, W. \& Smyth, G. K. voom: Precision weights unlock linear model analysis tools for RNA-seq read counts. Genome Biol 15, R29, doi:10.1186/gb-2014-15-2-r29 (2014).

43 Bruford, E. A. et al. Guidelines for human gene nomenclature. Nat Genet 52, 754-758, doi:10.1038/s41588-020-0669-3 (2020).

44 Boedigheimer, M. J. et al. Sources of variation in baseline gene expression levels from toxicogenomics study control animals across multiple laboratories. BMC Genomics 9, 285, doi:10.1186/1471-2164-9-285 (2008).

45 Bulteau, R. \& Francesconi, M. Real age prediction from the transcriptome with RAPToR. bioRxiv, 2021.2009.2007.459270, doi:10.1101/2021.09.07.459270 (2021).

46 Shah, N. et al. A crowdsourcing approach for reusing and meta-analyzing gene expression data. Nat Biotechnol 34, 803-806, doi:10.1038/nbt.3603 (2016). 
FIGURE LEGENDS:

513 Figure 1: HIPC Immune Signatures Data Resource pipeline and study demographics.

A. Systems vaccinology datasets from existing HIPC studies, as well as published systems vaccinology papers and databases, were submitted to the ImmPort database. ImmuneSpace captures these datasets to create a combined compendium dataset. Quality control assessments of these data include array quality checks for microarray studies, batch correction, imputations for

Figure 3: Quality control assessments of transcriptomics data. missing age and sex/y-chromosome presence information, and normalization per study. The combined virtual study included transcriptional profiles and antibody response measurements from 1405 participants across 53 cohorts, profiling the response to 24 different vaccines.

B. Demographic data included biological sex, race, vaccine, and number of participants.

Figure 2: Flow chart diagram of the Immune Signatures Data Resource. metrics package was employed to assess quality of microarray datasets by checking the following criteria: a.) absolute mean difference between arrays to check the probe and median intensity across all arrays, b.) Kolmogorov-Smirnov statistics to check the signal intensity distribution of arrays, comparing each probe versus distribution of test statistics for all other probes, c.) Hoeffding's Dstatistics for arrays. Arrays were excluded if they fail all three criteria above. baseline expression data per study before (B) and after batch correction (C). D. Biological sex imputation based on expression of Y-chromosome genes. We used 13 Ychromosome-associated genes to cluster samples into 2 groups assuming biological male or female. E-F. Age imputation based on transcriptomic profiles for studies without reported ages (SDY1260, SDY1264, SDY1293, SDY1294, SDY1364, SDY1370, SDY1373, SDY984) via the RAPToR R package $^{45}$. Virtual studies were split into young (age $<50, \mathbf{E}$ ) and older (age $>=50, \mathbf{F}$ ) for two separate predictive models. 
Figure 4: Immune Signatures Transcriptomics Overview for young and old datasets.

A. Number of samples available for each data type, including transcriptomics (TX), hemagglutination inhibition assay (HAI), neutralizing antibody assay (NAB), and ELISA assays (ELISA).

B. Bar plot depicting the number of samples at each time point. The colors within each bar indicate the breakdown for each unique combination of pathogen and vaccine type. Day -7 and day 0 correspond to times pre-vaccination.

\section{Figure 5: Immune Response Dataset Overview}

A. The longitudinal trajectory (summarized as a loess curve) of hemagglutinin inhibition assay (HAI) measurements (in $\log _{2}$ scale) by influenza vaccine type and year.

B. The longitudinal trajectory of neutralizing antibody (NAB) titers (in $\log 2$ scale) for influenza, meningococcus, pneumococcus, and yellow fever vaccines.

C. Neutralizing antibody titers were plotted for each unique combination of targeted pathogen and vaccine type to compare each participants' post-vaccination (day 28-30) values versus baseline (day 0). The violin plot shows the variation in magnitude for each unique combination of targeted pathogen and vaccine type.

D. The correlation plot of influenza studies compares the maximum fold change (MFC) across strains for hemagglutinin inhibition assay (HAI) titers versus neutralizing antibody (NAB) titers. 
bioRxiv preprint doi: https://doi.org/10.1101/2021.11.05.465336; this version posted November 8, 2021. The copyright holder for this preprint (which was not certified by peer review) is the author/funder, who has granted bioRxiv a license to display the preprint in perpetuity. It is made available under aCC-BY 4.0 International license. 
bioRxiv preprint doi: https://doi org/10.1101/2021.11.05.465336; this version posted November 8,2021 . The copyright holder for this preprint (4 ich was not certified by peer review) is the author/funder, who has granted bioRxiv a license to display the preprint in perpetuity. It is made

HIPC Centers available under aCC-BY 4.0 International license.
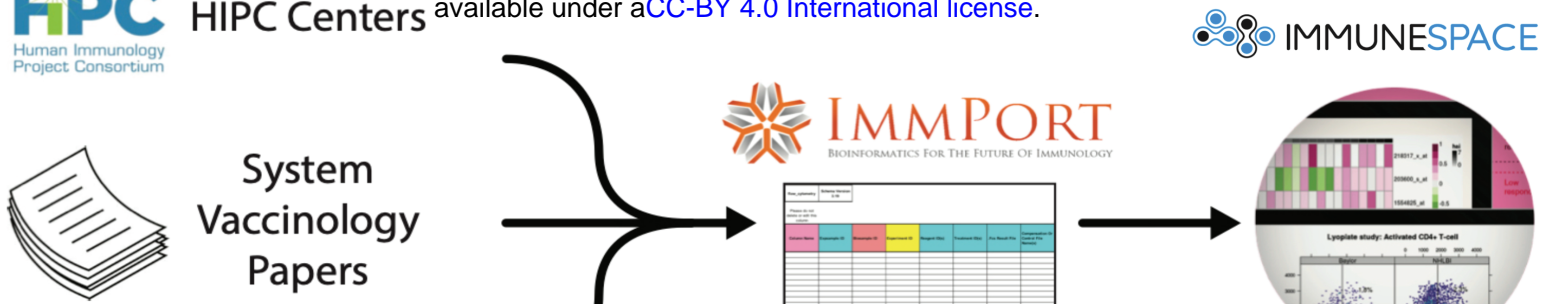

System

Vaccinology

Papers

Gen Expression
Omnibus
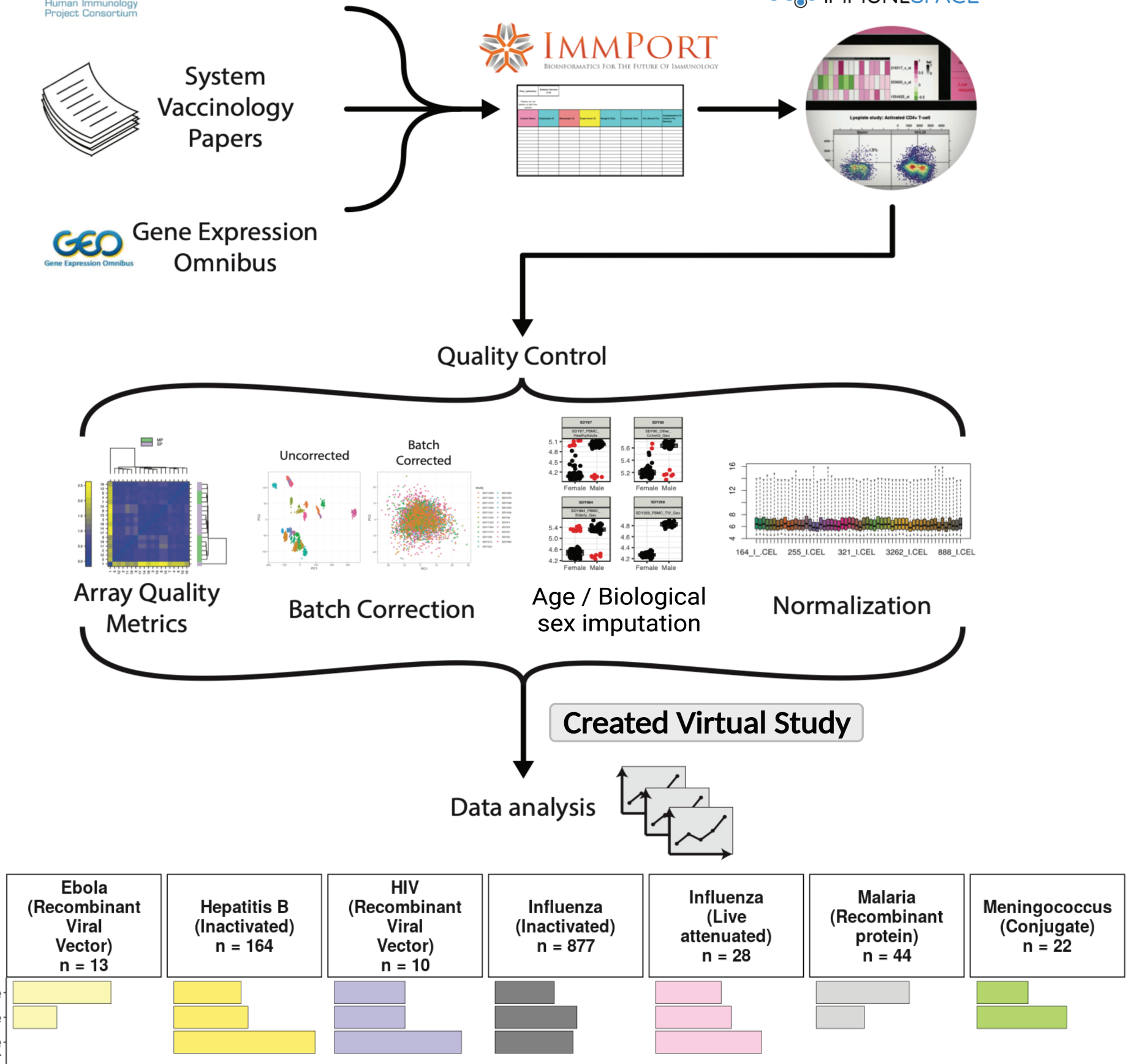

African American

Alaska Native

Other

Not Specified

Unknown
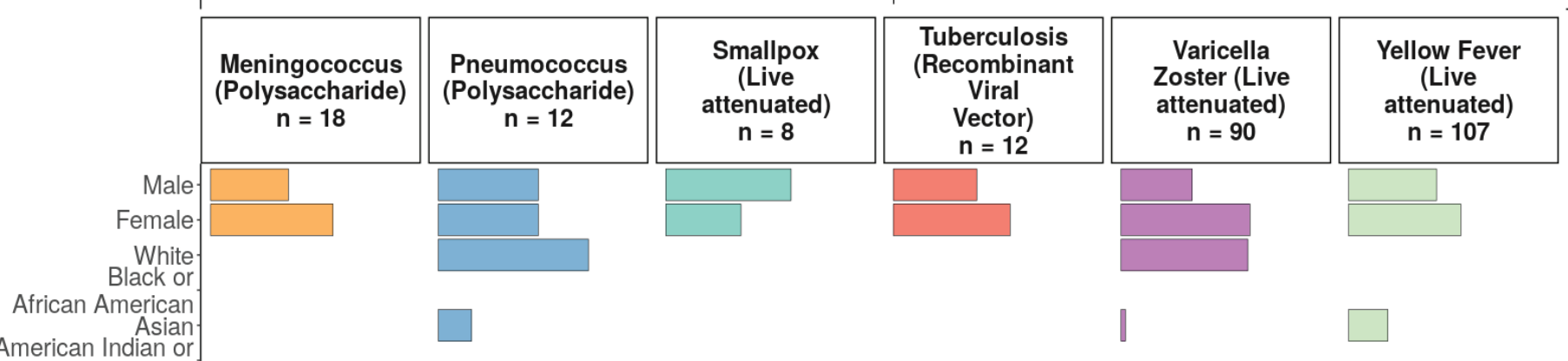

$0 v^{0} \times 6^{\circ} 8^{0} 1^{\circ}$

Alaska Native
Other

Not Specified

Unknown

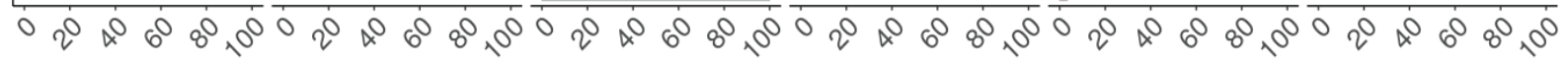

Distribution (\%) 
bioRxiv preprint doi: https://doi.org/10.1101/2021.11.05.465336; this version posted November 8, 2021. The copyright holder for this preprint (which was not certified by peer review) is the author/funder, who has granted bioRxiv a license to display the preprint in perpetuity. It is made
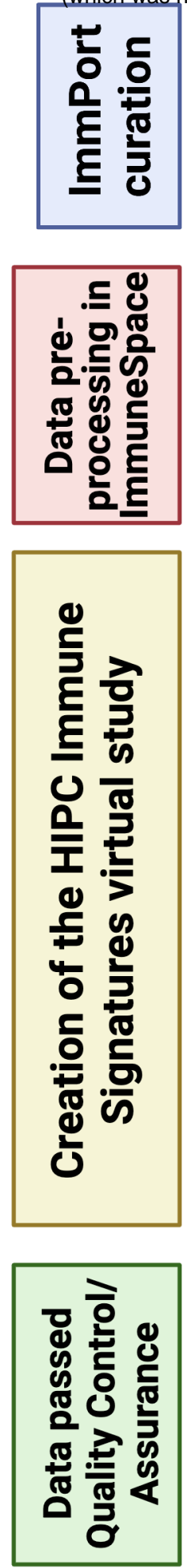

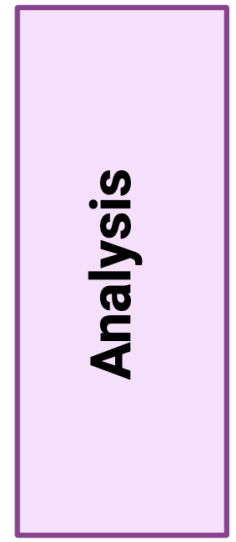

Literature and database search of vaccinology studies HIPC studies: 16;

Non-HIPC studies: 14;

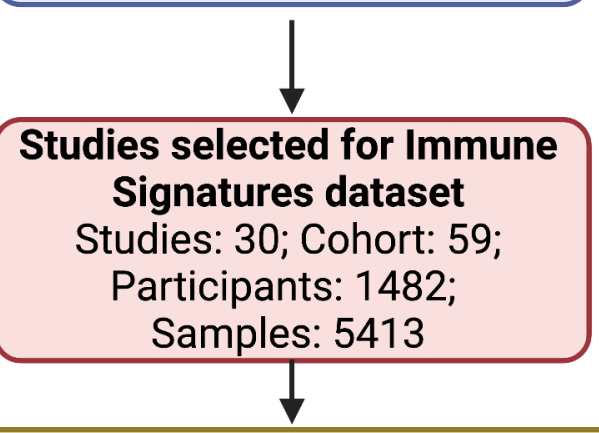

I. Cohorts removal based on inclusion/exclusion criteria* Remained: Studies: 30; Cohorts: 54; Participants: 1448; Samples: 5046

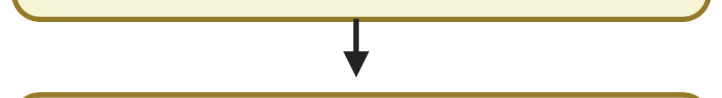

\section{Samples' removal due to differences on time design determination}

Remained: Studies: 30; Cohorts: 54; Participants: 1447; Samples: 4868

Ili. Participants' removal with no baseline samples

Remained: Studies: 30; Cohorts: 53; Participants: 1405; Samples: 4795
Studies pulled from Gene Expression Omnibus: 24
Affected: Studies: 4; Cohorts: 7; Participants: 42; Samples: 367 Dropped: Studies: 0; Cohorts: 5; Participants: 34; Samples: 367

All studies passed Array Quality Metrics check

Affected: Studies: 4; Cohorts: 5; Participants: 58; Samples: 178 Dropped: Studies: 0; Cohorts: 0; Participants: 1; Samples: 178

Affected: Studies: 7; Cohorts: 9; Participants: 42; Samples: 73 Dropped: Studies: 0; Cohorts: 1; Participants: 42; Samples: 73

\section{Across Study Normalization/ Batch Correction:}

All participants expression set

Studies: 30; Cohorts: 53

Participants: 1405

Samples: 4795

Young adult (18-49 yo) expression set

Studies: 28; Cohorts: 40

Participants: 820

Samples: 3177

Young adult (18-49 yo) eset with response variables Studies: 25; Cohorts: 34

Participants: 699

Samples: 2689
Elderly (60-90 yo) expression set

Studies: 14; Cohorts: 19

Participants: 456 Samples: 1247

Elderly (60-90 yo) eset with response variables

Studies: 13; Cohorts: 17

Participants: 404

Samples: 1066 
$\mathbf{A}$

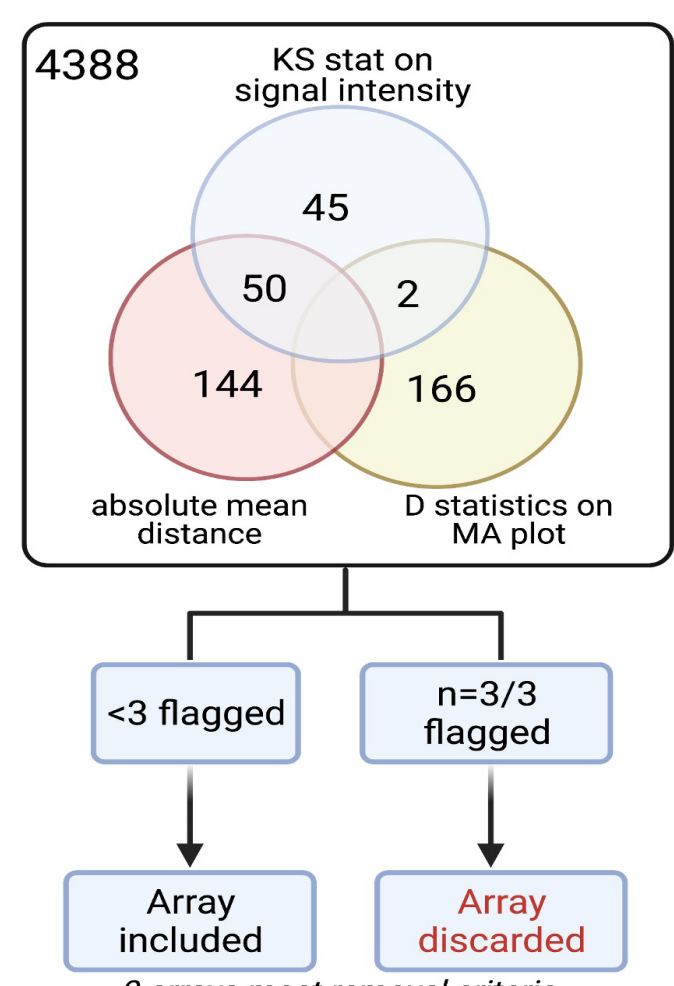

O arrays meet removal criteria
All arrays passed the criteria

\section{D}

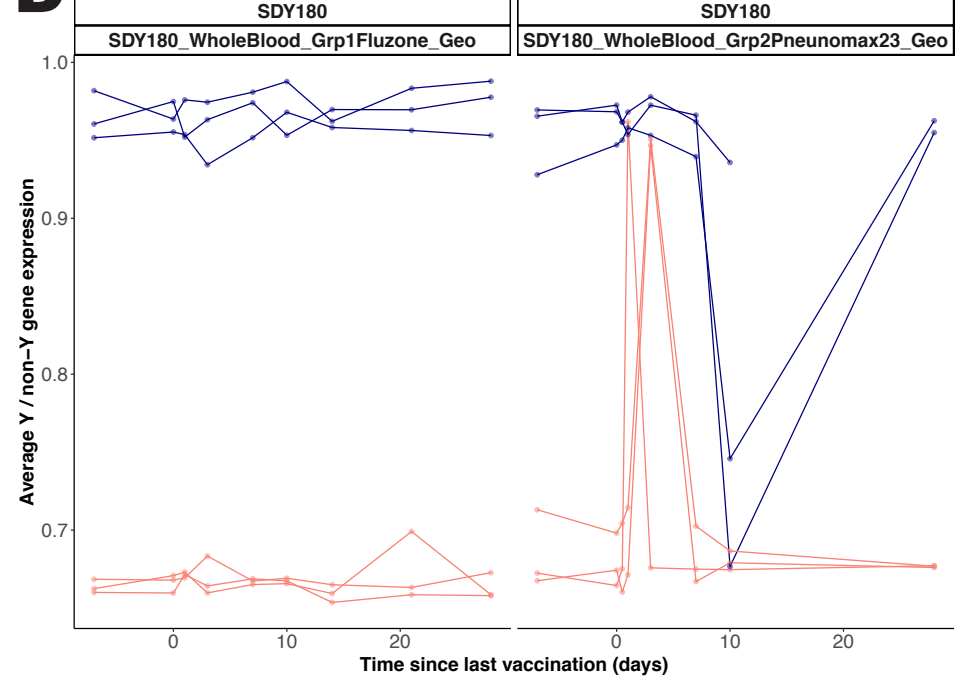

B
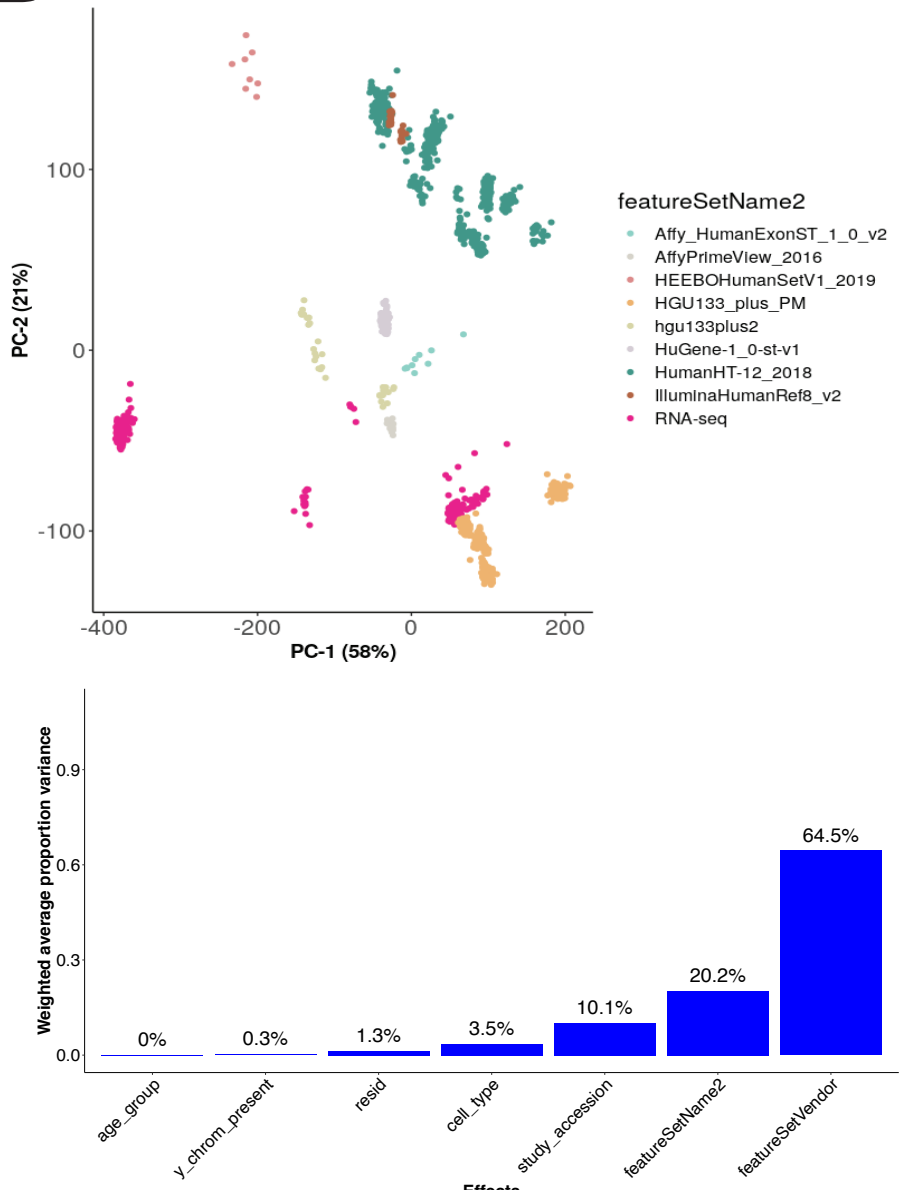

E

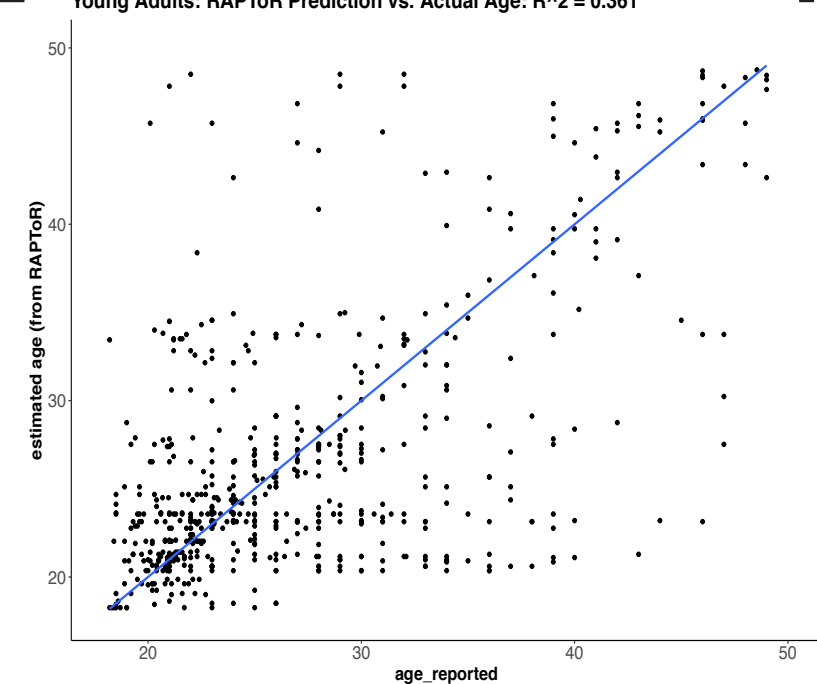

Baseline post-batch correction
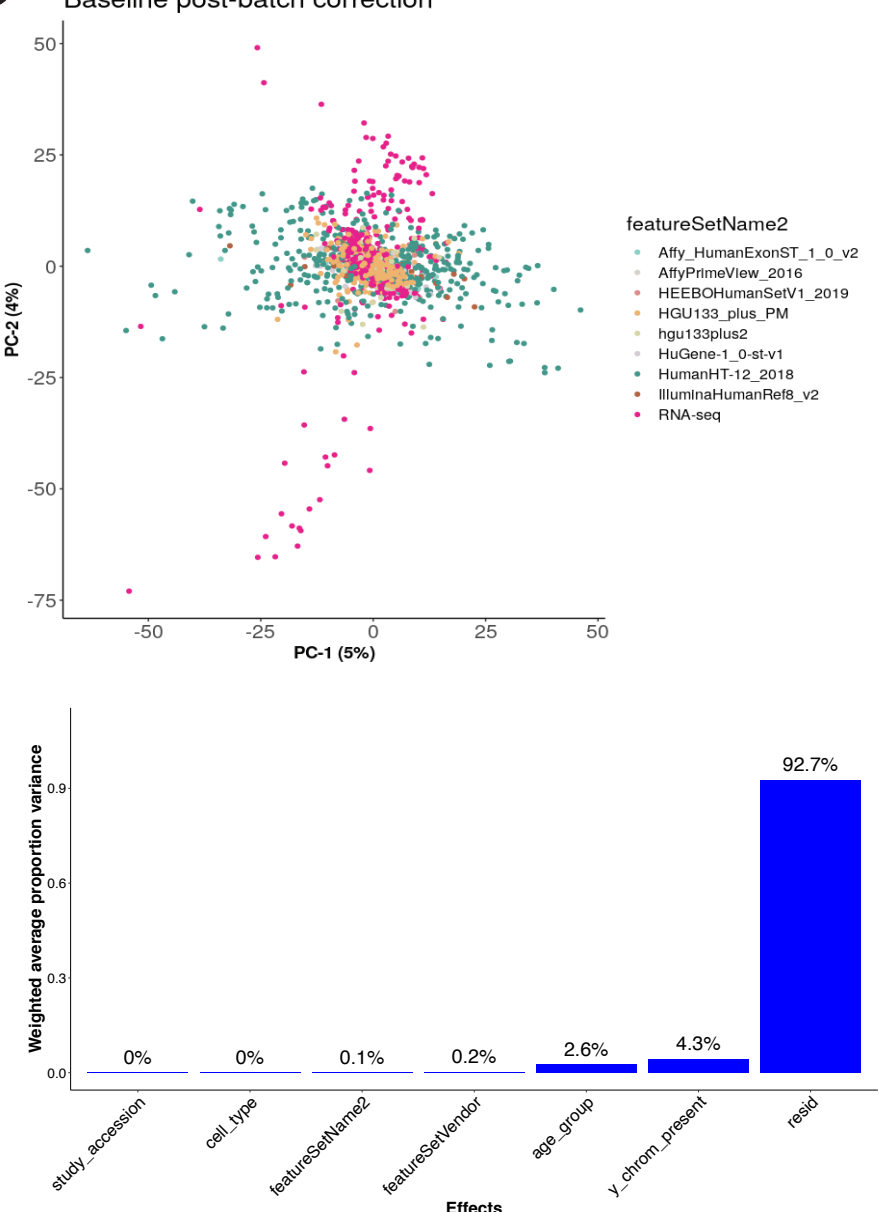

F

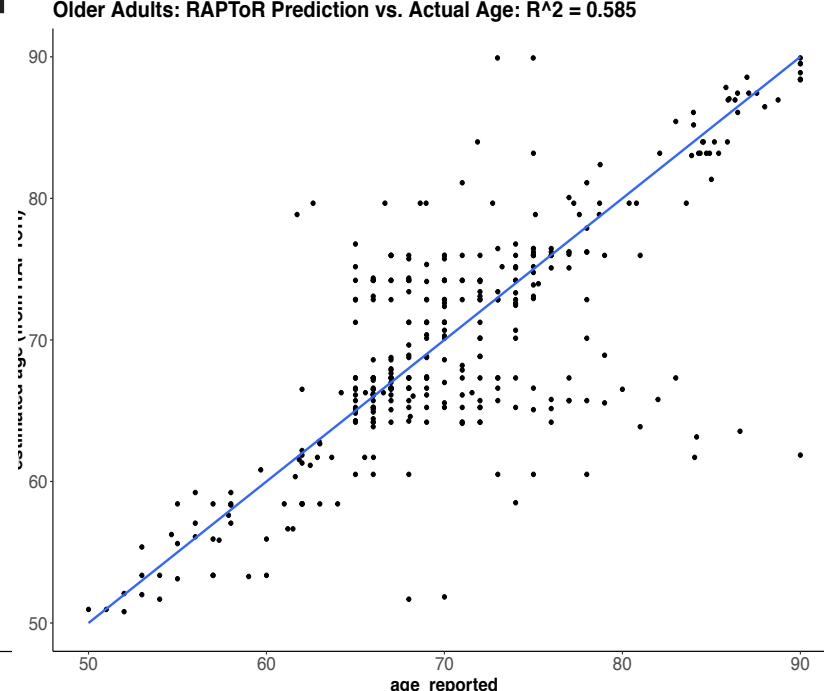


A

Pathogen (Vaccine Type) TX HAI NAB ELISA Ebola (Recombinant)

Hepatitis B (Inactivated)

HIV (Recombinant)

Influenza (Inactivated)

Influenza (Live attenuated)

Meningococcus (Conjugate)

Meningococcus (Polysaccharide)

Pneumococcus (Polysaccharide)

Small Pox (Live attenuated)

Tuberculosis (Recombinant)

Varicella Zoster (Live attenuated)

Yellow Fever (Live attenuated)

\begin{tabular}{|c|c|c|c|}
\hline 46 & & & \\
\hline 325 & & & 320 \\
\hline 50 & & & \\
\hline 3014 & 2516 & 339 & 0 \\
\hline 83 & 83 & & 84 \\
\hline 61 & & 0 & 51 \\
\hline 49 & & 10 & 39 \\
\hline 101 & & 54 & \\
\hline 48 & & & 48 \\
\hline 36 & & & 36 \\
\hline 324 & & & 140 \\
\hline 493 & & 460 & \\
\hline
\end{tabular}

Number of samples

C

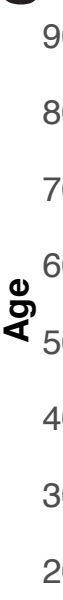

90
80
70
60
50
4
30
20

20

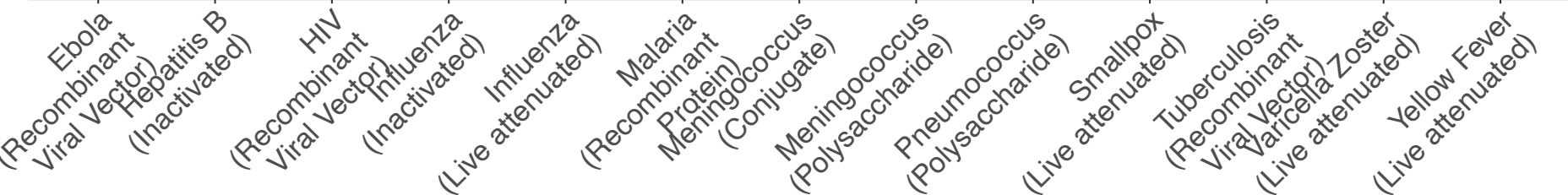

Pathogen (Vaccine Type)

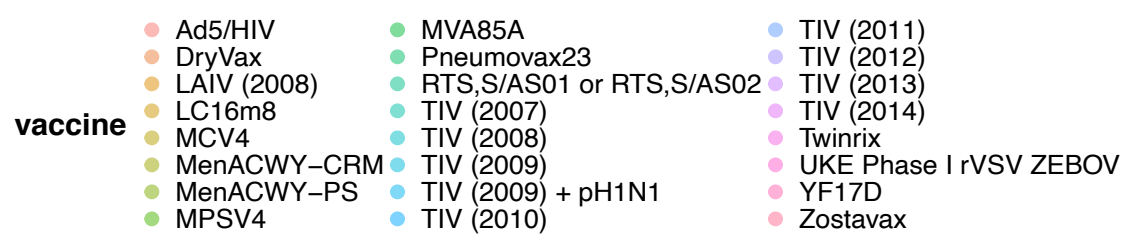

Female $\Delta$ Male (Y chrom presence)
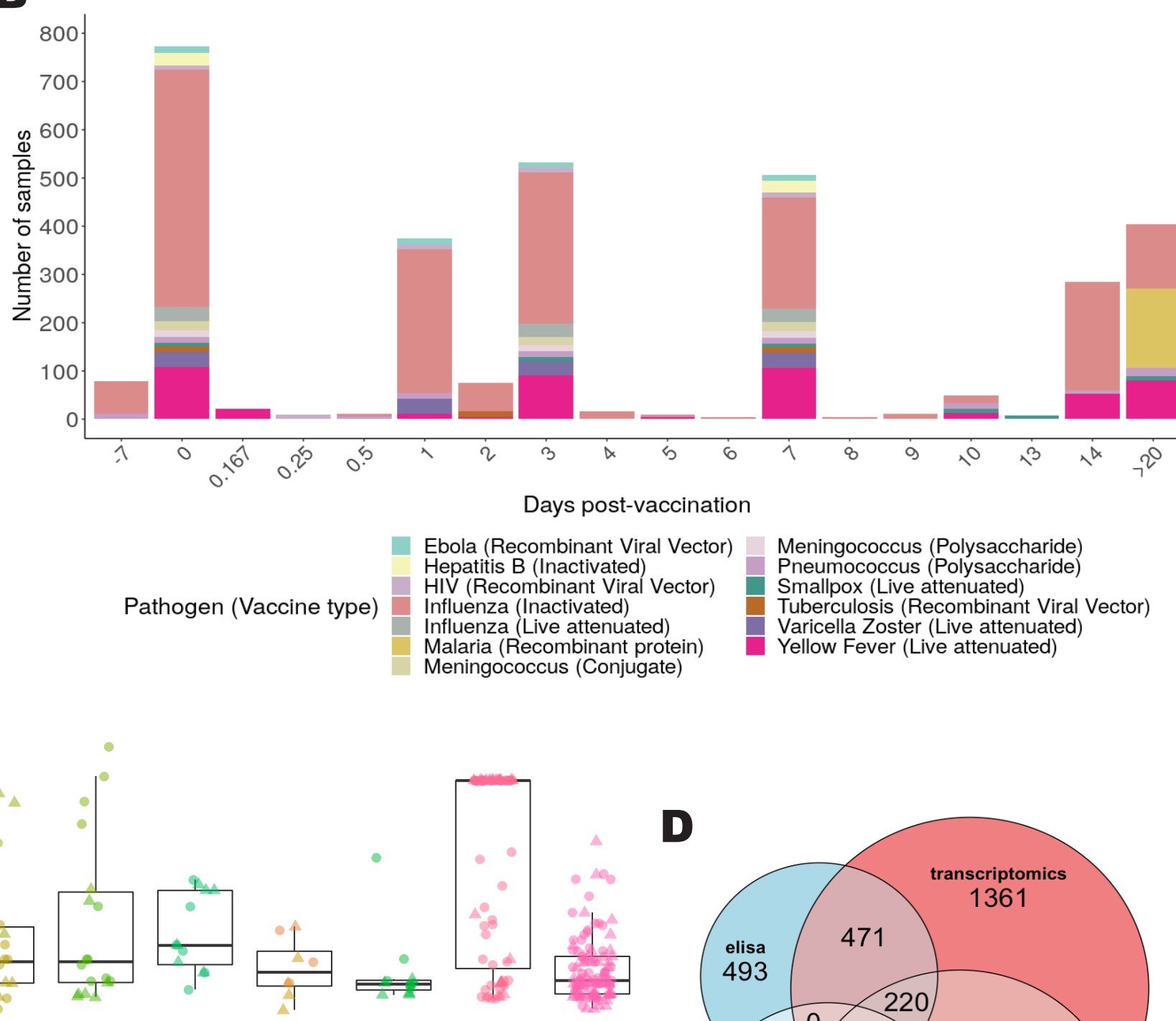

D

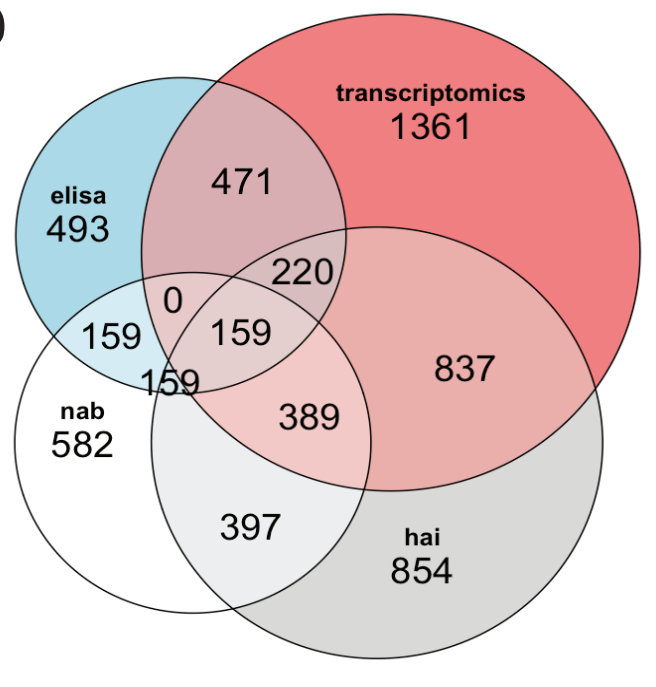


bioRxiv preprint doi: https://doi.org/10.1101/2021.11.05.465336; this version posted November 8 , 2021. The copyright holder for this preprint

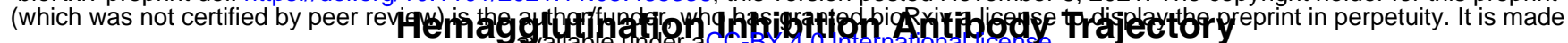
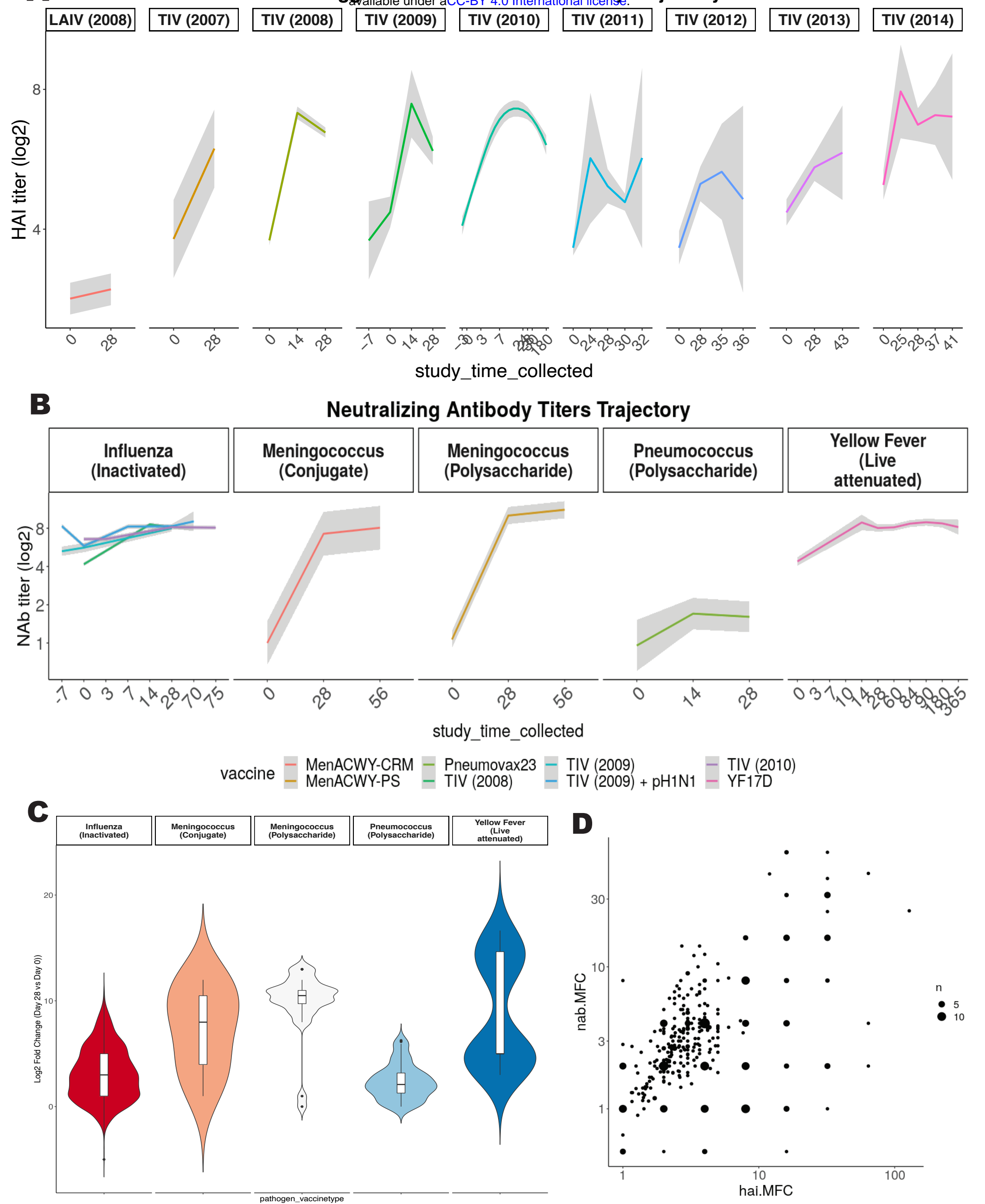
TABLES:

2 Table 1: Overview of Immune Signatures Data Resource Study Participants Metadata

\begin{tabular}{|c|c|c|c|c|c|c|c|c|c|c|}
\hline $\begin{array}{c}\text { Study } \\
\text { Accession }\end{array}$ & $\begin{array}{c}\text { Pathogen } \\
\text { (Vaccine } \\
\text { Type) }\end{array}$ & $\begin{array}{l}\text { Number of } \\
\text { Participants }\end{array}$ & $\begin{array}{l}\text { Number of } \\
\text { Samples }\end{array}$ & Vaccine & $\begin{array}{c}\text { Adjuva } \\
\text { nt }\end{array}$ & Race & Ethnicity & Cohort & Matrix & $\begin{array}{l}\text { Pubmed } \\
\text { ID }\end{array}$ \\
\hline SDY1373 & $\begin{array}{c}\text { Ebola } \\
\text { (Recombinant } \\
\text { Viral Vector) }\end{array}$ & 13 & 46 & $\begin{array}{c}\text { UKE } \\
\text { Phase I } \\
\text { rVSV } \\
\text { ZEBOV }\end{array}$ & VSV & $\begin{array}{c}\text { Not } \\
\text { Specified }\end{array}$ & $\begin{array}{c}\text { Not } \\
\text { Specified }\end{array}$ & $\begin{array}{c}\text { dose } \\
20 \times 10^{\wedge} 6 \\
\text { ofu,dose } \\
3 \times 10^{\wedge} 6 \text { pfu }\end{array}$ & $\begin{array}{c}\text { SDY1373_ } \\
\text { WholeBloo } \\
\text { d_highDose } \\
\text { _Geo,SDY } \\
\text { 1373_Whol } \\
\text { eBlood_lo } \\
\text { wDose_Ge } \\
\text { o }\end{array}$ & \\
\hline SDY1328 & $\begin{array}{l}\text { Hepatitis B } \\
\text { (Inactivated) }\end{array}$ & 164 & 325 & Twinrix & None & White & $\begin{array}{c}\text { Not } \\
\text { Hispanic or } \\
\text { Latino }\end{array}$ & $\begin{array}{l}\text { healthy } \\
\text { adults }\end{array}$ & $\begin{array}{c}\text { SDY1328_ } \\
\text { WholeBloo } \\
\text { d_Healthy } \\
\text { Aldults_Ge } \\
\text { o }\end{array}$ & 26742691 \\
\hline SDY1291 & $\begin{array}{c}\text { HIV } \\
\text { (Recombinant } \\
\text { Viral Vector) }\end{array}$ & 10 & 50 & Ad5/HIV & $\mathrm{AdV}$ & $\begin{array}{l}\text { White, } \\
\text { Black, or } \\
\text { African } \\
\text { American }\end{array}$ & $\begin{array}{c}\text { Not } \\
\text { Hispanic or } \\
\text { Latino }\end{array}$ & $\begin{array}{l}\text { healthy } \\
\text { HIV-1- } \\
\text { uninfected } \\
\text { adults }\end{array}$ & \begin{tabular}{|c} 
SDY1291_- \\
PBMC_He \\
althyHIVU \\
ninfected_ \\
Geo
\end{tabular} & 23151505 \\
\hline SDY1119 & $\begin{array}{l}\text { Influenza } \\
\text { (Inactivated) }\end{array}$ & 72 & 177 & $\begin{array}{c}\text { TIV } \\
(2011)\end{array}$ & None & $\begin{array}{c}\text { Not } \\
\text { Specified }\end{array}$ & $\begin{array}{c}\text { Not } \\
\text { Specified }\end{array}$ & \begin{tabular}{|} 
young T2D, \\
young \\
healthy,old \\
healthy old \\
T2D
\end{tabular} & $\begin{array}{c}\text { SDY1119_ } \\
\text { PBMC_you } \\
\text { ngT2D_Ge } \\
\text { o,SDY1119 } \\
\text { _PBMC_yo } \\
\text { ungHealthy } \\
\text { _Geo,SDY } \\
\text { 1119_PBM } \\
\text { C_oldHealt } \\
\text { hy_Geo,SD }\end{array}$ & 26682988 \\
\hline
\end{tabular}




\begin{tabular}{|c|c|c|c|c|c|c|c|c|c|c|}
\hline & & & & & & & & & $\begin{array}{c}\text { Y1119_PB } \\
\text { MC_oldT2 } \\
\text { D_Geo }\end{array}$ & \\
\hline SDY1276 & $\begin{array}{c}\text { Influenza } \\
\text { (Inactivated) }\end{array}$ & 218 & 828 & $\begin{array}{c}\text { TIV } \\
(2008)\end{array}$ & None & $\begin{array}{c}\text { Not } \\
\text { Specified }\end{array}$ & $\begin{array}{c}\text { Not } \\
\text { Specified }\end{array}$ & $\begin{array}{l}\text { Validation } \\
\text { Cohort; } \\
\text { Females } \\
\text { 2008-2009 } \\
\text { trivalent } \\
\text { influenza } \\
\text { vaccine } \\
\text {,Discovery } \\
\text { Cohort; } \\
\text { Males } \\
\text { 2008?2009 } \\
\text { trivalent } \\
\text { influenza } \\
\text { vaccine }\end{array}$ & $\begin{array}{c}\text { SDY1276_ } \\
\text { WholeBloo } \\
\mathrm{d}_{-} \text {Validatio } \\
\mathrm{n} \text { _Geo,SD } \\
\text { Y1276_Wh } \\
\text { oleBlood_ } \\
\text { Discovery_ } \\
\text { Geo }\end{array}$ & 21357945 \\
\hline SDY180 & $\begin{array}{c}\text { Influenza } \\
\text { (Inactivated) }\end{array}$ & 12 & 102 & $\begin{array}{c}\text { TIV } \\
(2009)\end{array}$ & None & $\begin{array}{c}\text { Asian ,Whit } \\
\text { e,Black or } \\
\text { African } \\
\text { American }\end{array}$ & $\begin{array}{c}\text { Not } \\
\text { Hispanic or } \\
\text { Latino }\end{array}$ & $\begin{array}{c}\text { Study } \\
\text { group } 2 \\
2009-2010 \\
\text { Fluzone,Stu } \\
\text { dy group } 1 \\
2009-2010 \\
\text { Fluzone }\end{array}$ & $\begin{array}{c}\text { SDY180_ } \\
\text { WholeBloo } \\
\text { d_Grp2Fluz } \\
\text { one_G } \\
\text { eo,SDY180 } \\
\text {-WholeBlo } \\
\text { od_Grp1Fl } \\
\text { uzone_Geo }\end{array}$ & 23601689 \\
\hline SDY212 & $\begin{array}{c}\text { Influenza } \\
\text { (Inactivated) }\end{array}$ & 90 & 90 & $\begin{array}{c}\text { TIV } \\
(2008)\end{array}$ & None & $\begin{array}{l}\text { Oth er,Wh } \\
\text { ite,As } \\
\text { ian,Americ } \\
\text { an I,ndian } \\
\text { or Alaska } \\
\text { Native }\end{array}$ & $\begin{array}{c}\text { Not } \\
\text { Hispanic or } \\
\text { L } \\
\text { atino,Hispa } \\
\text { nic or } \\
\text { Latino }\end{array}$ & $\begin{array}{c}\text { Cohort_1,C } \\
\text { ohort_2 }\end{array}$ & $\begin{array}{l}\text { SDY212_- } \\
\text { WholeBloo } \\
\text { d_Young_ } \\
\text { Geo,SDY2 } \\
\text { 12_PBMC_ } \\
\text { Young_geo } \\
\text {,SDY212_ } \\
\text { WholeBloo } \\
\text { d_Older_G }\end{array}$ & 23591775 \\
\hline
\end{tabular}




\begin{tabular}{|c|c|c|c|c|c|c|c|c|c|c|}
\hline & & & & & & & & & $\begin{array}{c}\text { eo,SDY212 } \\
\text {-PBMC_Ol } \\
\text { der_Geo }\end{array}$ & \\
\hline SDY224 & $\begin{array}{c}\text { Influenza } \\
\text { (Inactivated) }\end{array}$ & 5 & 55 & $\begin{array}{c}\text { TIV } \\
\text { (2010) }\end{array}$ & None & $\begin{array}{c}\text { White,Blac } \\
\text { k or } \\
\text { African } \\
\text { American, } \\
\text { American } \\
\text { Indian or } \\
\text { Alaska } \\
\text { Native }\end{array}$ & $\begin{array}{c}\text { Not } \\
\text { Hispanic or } \\
\text { Latino,Hisp } \\
\text { anic or } \\
\text { Latino }\end{array}$ & TIV 2010 & $\begin{array}{c}\text { SDY224_P } \\
\text { BMC_TIV } \\
\text { 2010_Imm } \\
\text { Port }\end{array}$ & 23900141 \\
\hline SDY269 & $\begin{array}{c}\text { Influenza } \\
\text { (Inactivated) }\end{array}$ & 28 & 80 & $\begin{array}{c}\text { TIV } \\
(2008)\end{array}$ & None & $\begin{array}{l}\text { White,Asia } \\
\text { n,Black or } \\
\text { African } \\
\text { American }\end{array}$ & \begin{tabular}{|c} 
Not \\
Hispanic or \\
Latino,Hisp \\
anic or \\
Latino \\
\end{tabular} & $\begin{array}{l}\text { TIV Group } \\
2008\end{array}$ & $\begin{array}{c}\text { SDY269_P } \\
\text { BMC_TIV } \\
\text { _Geo }\end{array}$ & 21743478 \\
\hline SDY270 & $\begin{array}{c}\text { Influenza } \\
\text { (Inactivated) }\end{array}$ & 28 & 83 & $\begin{array}{c}\text { TIV } \\
\text { (2009) }\end{array}$ & None & $\begin{array}{c}\text { White,Blac } \\
\text { k or } \\
\text { African } \\
\text { American, } \\
\text { Asian } \\
\end{array}$ & $\begin{array}{c}\text { Not } \\
\text { Hispanic or } \\
\text { Latino,Hisp } \\
\text { anic or } \\
\text { Latino } \\
\end{array}$ & $\begin{array}{c}\text { TIV Group } \\
2009\end{array}$ & $\begin{array}{l}\text { SDY270_P } \\
\text { BMC_TIV } \\
\text { Group_Geo }\end{array}$ & 21743478 \\
\hline SDY400 & $\begin{array}{c}\text { Influenza } \\
\text { (Inactivated) }\end{array}$ & 30 & 120 & $\begin{array}{c}\text { TIV } \\
\text { (2012) }\end{array}$ & None & $\begin{array}{l}\text { White,Asia } \\
\text { n,Black or } \\
\text { African } \\
\text { American, } \\
\text { Other }\end{array}$ & $\begin{array}{c}\text { Not } \\
\text { Hispanic or } \\
\text { Latino,Hisp } \\
\text { anic or } \\
\text { Latino }\end{array}$ & $\begin{array}{c}\text { Young } \\
\text { adults } 21- \\
30 \text { years } \\
\text { old,Older } \\
\text { adults }>= \\
65 \text { years } \\
\text { old }\end{array}$ & $\begin{array}{c}\text { SDY400_P } \\
\text { BMC_You } \\
\text { ng_Geo,SD } \\
\text { Y400_PBM } \\
\text { C_Older_G } \\
\text { eo }\end{array}$ & 32060136 \\
\hline SDY404 & $\begin{array}{c}\text { Influenza } \\
\text { (Inactivated) }\end{array}$ & 39 & 156 & $\begin{array}{l}\text { TIV } \\
\text { (2011) }\end{array}$ & None & $\begin{array}{c}\text { White,Unk } \\
\text { nown,Other } \\
\text {,Asian,Blac } \\
\text { k or } \\
\text { African }\end{array}$ & $\begin{array}{c}\text { Not } \\
\text { Hispanic or } \\
\text { Latino,Hisp } \\
\text { anic or } \\
\text { Latino }\end{array}$ & $\begin{array}{c}\text { Young } \\
\text { adults } 21- \\
30 \text { years } \\
\text { old,Older } \\
\text { adults >= }\end{array}$ & $\begin{array}{l}\text { SDY404_P } \\
\text { BMC_You } \\
\text { ng_Geo,SD } \\
\text { Y404_PBM } \\
\text { C_Older_G }\end{array}$ & 25596819 \\
\hline
\end{tabular}




\begin{tabular}{|c|c|c|c|c|c|c|c|c|c|c|}
\hline & & & & & & American & & $\begin{array}{l}65 \text { years } \\
\text { old }\end{array}$ & eo & \\
\hline SDY520 & $\begin{array}{c}\text { Influenza } \\
\text { (Inactivated) }\end{array}$ & 24 & 94 & $\begin{array}{c}\text { TIV } \\
(2013)\end{array}$ & None & $\begin{array}{l}\text { White,Asia } \\
\text { n,Black or } \\
\text { African } \\
\text { American }\end{array}$ & $\begin{array}{c}\text { Not } \\
\text { Hispanic or } \\
\text { Latino,Hisp } \\
\text { anic or } \\
\text { Latino }\end{array}$ & $\begin{array}{c}\text { Young } \\
\text { adults } 21 \text { - } \\
30 \text { years } \\
\text { old,Older } \\
\text { adults >= } \\
65 \text { years } \\
\text { old }\end{array}$ & $\begin{array}{c}\text { SDY520_ } \\
\text { WholeBloo } \\
\text { d_Young_g } \\
\text { eo,SDY520 } \\
\text {-WholeBlo } \\
\text { od_Older_ } \\
\text { Geo }\end{array}$ & 32060136 \\
\hline SDY56 & $\begin{array}{c}\text { Influenza } \\
\text { (Inactivated) }\end{array}$ & 63 & 288 & $\begin{array}{c}\text { TIV } \\
(2010)\end{array}$ & None & $\begin{array}{l}\text { White,Asia } \\
\text { n,Black or } \\
\text { African } \\
\text { American }\end{array}$ & $\begin{array}{c}\text { Not } \\
\text { Hispanic or } \\
\text { Latino,Hisp } \\
\text { anic or } \\
\text { Latino }\end{array}$ & $\begin{array}{c}\text { Healthy } \\
\text { adults } 25- \\
40 \text { years } \\
\text { old } \\
\text { receiving } \\
\text { TIV flu } \\
\text { vaccine,He } \\
\text { althy adults } \\
>65 \text { years } \\
\text { old } \\
\text { receiving } \\
\text { TIV flu } \\
\text { vaccine }\end{array}$ & $\begin{array}{c}\text { SDY56_PB } \\
\text { MC_Young } \\
\text {,SDY56_P } \\
\text { BMC_Olde } \\
\text { r }\end{array}$ & 26682988 \\
\hline SDY61 & $\begin{array}{c}\text { Influenza } \\
\text { (Inactivated) }\end{array}$ & 9 & 27 & $\begin{array}{c}\text { TIV } \\
(2007)\end{array}$ & None & White & $\begin{array}{c}\text { Not } \\
\text { Hispanic or } \\
\text { Latino,Hisp } \\
\text { anic or } \\
\text { Latino }\end{array}$ & $\begin{array}{l}\text { TIV Group } \\
2007\end{array}$ & $\begin{array}{c}\text { SDY61_PB } \\
\text { MC_TIVGr } \\
p\end{array}$ & 21743478 \\
\hline SDY63 & $\begin{array}{c}\text { Influenza } \\
\text { (Inactivated) }\end{array}$ & 19 & 72 & $\begin{array}{c}\text { TIV } \\
(2010)\end{array}$ & None & $\begin{array}{c}\text { White,Asia } \\
\text { n,Other,Bla } \\
\text { ck or } \\
\text { African } \\
\text { American }\end{array}$ & $\begin{array}{c}\text { Not } \\
\text { Hispanic or } \\
\text { Latino }\end{array}$ & $\begin{array}{c}\text { Young } \\
\text { adults } 21- \\
30 \text { years } \\
\text { old,Older } \\
\text { adults }>= \\
65 \text { years } \\
\text { old }\end{array}$ & $\begin{array}{l}\text { SDY63_PB } \\
\text { MC_Young } \\
\text { _Geo,SDY } \\
\text { 63_PBMC_ } \\
\text { Older_Geo }\end{array}$ & 25596819 \\
\hline
\end{tabular}




\begin{tabular}{|c|c|c|c|c|c|c|c|c|c|c|}
\hline SDY640 & $\begin{array}{c}\text { Influenza } \\
\text { (Inactivated) }\end{array}$ & 20 & 79 & $\begin{array}{c}\text { TIV } \\
(2014)\end{array}$ & None & $\begin{array}{l}\text { White,Asia } \\
\text { n,Unknown }\end{array}$ & $\begin{array}{c}\text { Not } \\
\text { Hispanic or } \\
\text { Latino,Hisp } \\
\text { anic or } \\
\text { Latino }\end{array}$ & \begin{tabular}{|c} 
Young \\
adults $21-$ \\
30 years \\
old,Older \\
adults >= \\
65 years \\
old
\end{tabular} & $\begin{array}{c}\text { SDY640_ } \\
\text { WholeBloo } \\
\text { d_Young_ } \\
\text { Geo,SDY6 } \\
\text { 40_WholeB } \\
\text { lood_Older } \\
\text { _Geo }\end{array}$ & 32060136 \\
\hline SDY80 & $\begin{array}{c}\text { Influenza } \\
\text { (Inactivated) }\end{array}$ & 61 & 286 & $\begin{array}{c}\text { TIV } \\
(2009)+ \\
\text { pH1N1 }\end{array}$ & None & $\begin{array}{c}\text { White,Asia } \\
\text { n,Other,Bla } \\
\text { ck or } \\
\text { African } \\
\text { American }\end{array}$ & $\begin{array}{c}\text { Other,Hispa } \\
\text { nic or } \\
\text { Latino }\end{array}$ & Cohort2 & $\begin{array}{c}\text { SDY80_PB } \\
\text { MC_Cohort } \\
\text { 2_geo }\end{array}$ & 24725414 \\
\hline SDY269 & $\begin{array}{c}\text { Influenza (Live } \\
\text { attenuated) }\end{array}$ & 28 & 83 & $\begin{array}{l}\text { LAIV } \\
(2008)\end{array}$ & LAIV & $\begin{array}{c}\text { White,Blac } \\
\text { k or } \\
\text { African } \\
\text { American, } \\
\text { Asian }\end{array}$ & $\begin{array}{c}\text { Not } \\
\text { Hispanic or } \\
\text { Latino,Hisp } \\
\text { anic or } \\
\text { Latino }\end{array}$ & \begin{tabular}{|c} 
LAIV \\
group 2008
\end{tabular} & $\begin{array}{c}\text { SDY269_P } \\
\text { BMC_LAI } \\
\text { V_Geo }\end{array}$ & 21743478 \\
\hline SDY1293 & $\begin{array}{c}\text { Malaria } \\
\text { (Recombinant } \\
\text { protein) }\end{array}$ & 44 & 165 & $\begin{array}{c}\text { RTS,S/A } \\
\text { S01 or } \\
\text { RTS,S/A } \\
\text { S02 }\end{array}$ & $\begin{array}{c}\text { AS01/A } \\
\text { S02 }\end{array}$ & $\begin{array}{c}\text { Not } \\
\text { Specified }\end{array}$ & $\begin{array}{c}\text { Not } \\
\text { Specified }\end{array}$ & \begin{tabular}{|c} 
adjuvanted \\
RTS,S \\
malaria \\
vaccine \\
cohort
\end{tabular} & $\begin{array}{c}\text { SDY1293_- } \\
\text { PBMC_Va } \\
\text { ccinated_ge } \\
\text { o }\end{array}$ & \\
\hline SDY1260 & $\begin{array}{c}\text { Meningococcus } \\
\text { (Conjugate) }\end{array}$ & 17 & 51 & MCV4 & None & $\begin{array}{c}\text { Not } \\
\text { Specified }\end{array}$ & $\begin{array}{c}\text { Not } \\
\text { Specified }\end{array}$ & MCV4 & $\begin{array}{l}\text { SDY1260_ } \\
\text { PBMC_MC } \\
\text { V4_Geo }\end{array}$ & 24336226 \\
\hline SDY1325 & $\begin{array}{c}\text { Meningococcus } \\
\text { (Conjugate) }\end{array}$ & 5 & 10 & $\begin{array}{c}\text { MenAC } \\
\text { WY- } \\
\text { CRM }\end{array}$ & None & $\begin{array}{c}\text { Not } \\
\text { Specified }\end{array}$ & $\begin{array}{c}\text { Not } \\
\text { Specified }\end{array}$ & $\begin{array}{c}\text { Intramuscul } \\
\text { ar } \\
\text { MenACW } \\
\text { Y-CRM }\end{array}$ & $\begin{array}{c}\text { SDY1325_ } \\
\text { WholeBloo } \\
\text { d_Intramus } \\
\text { cularCRM_ } \\
\text { Geo }\end{array}$ & 28137280 \\
\hline SDY1260 & $\begin{array}{c}\text { Meningococcus } \\
\text { (Polysaccharide } \\
\text { ) }\end{array}$ & 13 & 39 & MPSV4 & None & $\begin{array}{c}\text { Not } \\
\text { Specified }\end{array}$ & $\begin{array}{c}\text { Not } \\
\text { Specified }\end{array}$ & MPSV4 & $\begin{array}{c}\text { SDY1260_ } \\
\text { PBMC_MP } \\
\text { SV4_Geo }\end{array}$ & 24336226 \\
\hline
\end{tabular}




\begin{tabular}{|c|c|c|c|c|c|c|c|c|c|c|}
\hline SDY1325 & $\begin{array}{c}\text { Meningococcus } \\
\text { (Polysaccharide } \\
\text { ) }\end{array}$ & 5 & 10 & $\begin{array}{l}\text { MenAC } \\
\text { WY-PS }\end{array}$ & None & $\begin{array}{c}\text { Not } \\
\text { Specified }\end{array}$ & $\begin{array}{c}\text { Not } \\
\text { Specified }\end{array}$ & $\begin{array}{c}\text { Intramuscul } \\
\text { ar } \\
\text { MenACW } \\
\text { Y-PS }\end{array}$ & $\begin{array}{c}\text { SDY1325_ } \\
\text { WholeBloo } \\
\text { d_Intramus } \\
\text { cularPS_Ge } \\
\text { o }\end{array}$ & 28137280 \\
\hline SDY180 & $\begin{array}{c}\text { Pneumococcus } \\
\text { (Polysaccharide } \\
\text { ) }\end{array}$ & 12 & 101 & $\begin{array}{l}\text { Pneumov } \\
\text { ax23 }\end{array}$ & None & $\begin{array}{c}\text { White,Blac } \\
\text { k or } \\
\text { African } \\
\text { American, } \\
\text { Asian }\end{array}$ & $\begin{array}{c}\text { Not } \\
\text { Hispanic or } \\
\text { Latino,Hisp } \\
\text { anic or } \\
\text { Latino }\end{array}$ & $\begin{array}{c}\text { Study } \\
\text { group } 2 \\
\text { Pneunomax } \\
23, \text { Study } \\
\text { group 1 } \\
\text { Pneunomax } \\
23\end{array}$ & $\begin{array}{c}\text { SDY180_ } \\
\text { WholeBloo } \\
\text { d_Grp2Pne } \\
\text { unomax23_- } \\
\text { Geo,SDY1 } \\
\text { 80_WholeB } \\
\text { lood_Grp1 } \\
\text { Pneunomax } \\
\text { 23_Geo }\end{array}$ & 23601689 \\
\hline SDY1370 & $\begin{array}{c}\text { Smallpox (Live } \\
\text { attenuated) }\end{array}$ & 4 & 24 & DryVax & $\begin{array}{l}\text { Vaccini } \\
\text { a }\end{array}$ & Unknown & $\begin{array}{c}\text { Not } \\
\text { Specified }\end{array}$ & DryVax & $\begin{array}{l}\text { SDY1370_ } \\
\text { PBMC_dry } \\
\text { vax_geo }\end{array}$ & 21921208 \\
\hline SDY1370 & $\begin{array}{c}\text { Smallpox (Live } \\
\text { attenuated) }\end{array}$ & 4 & 24 & $\mathrm{LC} 16 \mathrm{~m} 8$ & $\begin{array}{l}\text { Vaccini } \\
\text { a }\end{array}$ & Unknown & $\begin{array}{c}\text { Not } \\
\text { Specified }\end{array}$ & LC16m8 & $\begin{array}{l}\text { SDY1370_ } \\
\text { PBMC_lc1 } \\
\text { 6m8_geo }\end{array}$ & 21921208 \\
\hline SDY1364 & $\begin{array}{l}\text { Tuberculosis } \\
\text { (Recombinant } \\
\text { Viral Vector) }\end{array}$ & 12 & 36 & $\begin{array}{c}\text { MVA85 } \\
\text { A }\end{array}$ & $\begin{array}{l}\text { Vaccini } \\
\text { a }\end{array}$ & $\begin{array}{c}\text { Not } \\
\text { Specified }\end{array}$ & $\begin{array}{c}\text { Not } \\
\text { Specified }\end{array}$ & $\begin{array}{l}\text { MVA85A } \\
\text { intramuscul } \\
\text { ar }\end{array}$ & $\begin{array}{l}\text { SDY1364_ } \\
\text { PBMC_Intr } \\
\text { aMuscular_ } \\
\text { Geo }\end{array}$ & 23844129 \\
\hline SDY984 & $\begin{array}{c}\text { Varicella } \\
\text { Zoster (Live } \\
\text { attenuated) }\end{array}$ & 72 & 288 & Zostavax & VZV & $\begin{array}{c}\text { White, Blac } \\
\text { k or } \\
\text { African } \\
\text { American, } \\
\text { Unknown, } \\
\text { Asian }\end{array}$ & $\begin{array}{c}\text { Not } \\
\text { Hispanic or } \\
\text { Latino,Hisp } \\
\text { anic or } \\
\text { Latino }\end{array}$ & $\begin{array}{c}\text { young,elder } \\
\text { ly }\end{array}$ & $\begin{array}{c}\text { SDY984_P } \\
\text { BMC_You } \\
\text { ng_Geo,SD } \\
\text { Y984_PBM } \\
\text { C_Elderly_ } \\
\quad \text { Geo }\end{array}$ & 28502771 \\
\hline SDY1264 & $\begin{array}{c}\text { Yellow Fever } \\
\text { (Live } \\
\text { attenuated) }\end{array}$ & 25 & 87 & YF17D & YF17D & $\begin{array}{c}\text { Not } \\
\text { Specified }\end{array}$ & $\begin{array}{c}\text { Not } \\
\text { Specified }\end{array}$ & $\begin{array}{c}\text { Trial2,Trial } \\
1\end{array}$ & $\begin{array}{l}\text { SDY1264_- } \\
\text { PBMC_Tri } \\
\text { al2_Geo,S }\end{array}$ & 19029902 \\
\hline
\end{tabular}




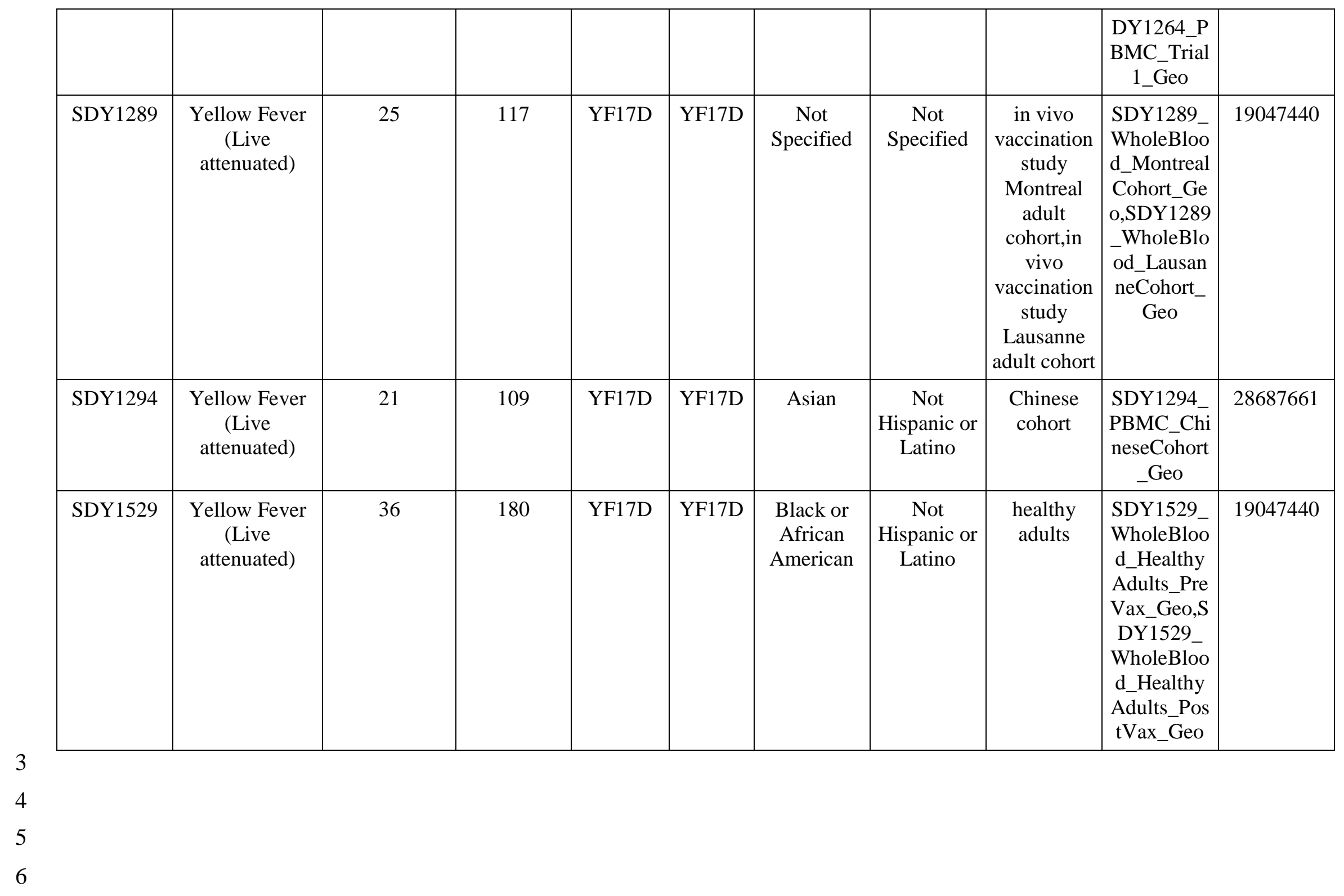


8 Table 2: Overview of Transcriptomics Datasets Included in the Resource

\begin{tabular}{|c|c|c|c|c|c|c|c|}
\hline $\begin{array}{c}\text { Study } \\
\text { Accession }\end{array}$ & $\begin{array}{c}\text { Pathogen } \\
\text { (Vaccine type) }\end{array}$ & Sample type & $\begin{array}{c}\text { featureSetNa } \\
\text { me }\end{array}$ & $\begin{array}{c}\text { featureSetNa } \\
\text { me2 }\end{array}$ & $\begin{array}{c}\text { featureSetVen } \\
\text { dor }\end{array}$ & $\begin{array}{c}\text { Time post last } \\
\text { vaccination }\end{array}$ & $\begin{array}{c}\text { GEO } \\
\text { Accession }\end{array}$ \\
\hline SDY1373 & $\begin{array}{c}\text { Ebola } \\
\text { (Recombinant } \\
\text { Viral Vector) }\end{array}$ & Whole blood & $\begin{array}{l}\text { SDY1373_cust } \\
\text { omAnno }\end{array}$ & RNA-seq & NA & $0,1,3,7$ & GSE97590 \\
\hline SDY1328 & $\begin{array}{c}\text { Hepatitis B } \\
\text { (Inactivated) }\end{array}$ & Whole blood & $\begin{array}{c}\text { Affy_HumanR } \\
\text { STAcustom }\end{array}$ & RNA-seq & Affymetrix & 0,7 & GSE65834 \\
\hline SDY1291 & $\begin{array}{c}\text { HIV } \\
\text { (Recombinant } \\
\text { Viral Vector) } \\
\end{array}$ & PBMC & $\begin{array}{l}\text { Affy_HumanE } \\
\text { xonST_1_0_v2 }\end{array}$ & $\begin{array}{l}\text { Affy_HumanE } \\
\text { xonST_1_0_v2 }\end{array}$ & Affymetrix & $0,0.25,1,3,7$ & GSE22768 \\
\hline SDY1119 & $\begin{array}{c}\text { Influenza } \\
\text { (Inactivated) }\end{array}$ & PBMC & $\begin{array}{c}\text { HGU133_plus_ } \\
\text { PM }\end{array}$ & $\begin{array}{c}\text { HGU133_plus_ } \\
\text { PM }\end{array}$ & Affymetrix & $0,3,7$ & GSE74817 \\
\hline SDY1276 & $\begin{array}{c}\text { Influenza } \\
\text { (Inactivated) }\end{array}$ & Whole blood & $\begin{array}{l}\text { HumanHT- } \\
\text { 12_v3_2018 }\end{array}$ & $\begin{array}{l}\text { HumanHT- } \\
12 \_2018\end{array}$ & Illumina & $0,1,3,14$ & $\begin{array}{c}\text { GSE48024/GS } \\
\text { E48018 }\end{array}$ \\
\hline SDY180 & $\begin{array}{c}\text { Influenza } \\
\text { (Inactivated) }\end{array}$ & Whole blood & $\begin{array}{l}\text { HumanHT- } \\
\text { 12_v3_2018 }\end{array}$ & $\begin{array}{l}\text { HumanHT- } \\
\text { 12_2018 }\end{array}$ & Illumina & $\begin{array}{c}- \\
7,0,0.5,1,3,7,10 \\
, 14,21,28 \\
\end{array}$ & GSE48762 \\
\hline SDY212 & $\begin{array}{c}\text { Influenza } \\
\text { (Inactivated) }\end{array}$ & Whole blood & $\begin{array}{l}\text { HumanHT- } \\
\text { 12_v3_2018 }\end{array}$ & $\begin{array}{c}\text { HumanHT- } \\
12 \_2018\end{array}$ & Illumina & 0 & GSE41080 \\
\hline SDY224 & $\begin{array}{c}\text { Influenza } \\
\text { (Inactivated) }\end{array}$ & PBMC & $\begin{array}{c}\text { SDY224_Custo } \\
\text { mAnno }\end{array}$ & RNA-seq & NA & $\begin{array}{c}0,1,2,3,4,5,6,7 \\
8,9,10\end{array}$ & GSE45735 \\
\hline SDY269 & $\begin{array}{c}\text { Influenza } \\
\text { (Inactivated) }\end{array}$ & PBMC & $\begin{array}{c}\text { HGU133_plus_ } \\
\text { PM }\end{array}$ & $\begin{array}{c}\text { HGU133_plus_ } \\
\text { PM }\end{array}$ & Affymetrix & $0,3,7$ & $\begin{array}{c}\text { GSE29615/GS } \\
\text { E29617/GSE29 } \\
614\end{array}$ \\
\hline SDY270 & $\begin{array}{c}\text { Influenza } \\
\text { (Inactivated) }\end{array}$ & PBMC & $\begin{array}{c}\text { HGU133_plus_ } \\
\text { PM }\end{array}$ & $\begin{array}{c}\text { HGU133_plus_ } \\
\text { PM }\end{array}$ & Affymetrix & $0,3,7$ & $\begin{array}{c}\text { GSE29617/GS } \\
\text { E29614 }\end{array}$ \\
\hline SDY400 & $\begin{array}{c}\text { Influenza } \\
\text { (Inactivated) }\end{array}$ & PBMC & $\begin{array}{l}\text { HumanHT- } \\
12 \_v 4 \_2018\end{array}$ & $\begin{array}{l}\text { HumanHT- } \\
12 \_2018\end{array}$ & Illumina & $0,2,4,7,28$ & $\begin{array}{c}\text { GSE59743/GS } \\
\text { E95584 }\end{array}$ \\
\hline SDY404 & $\begin{array}{c}\text { Influenza } \\
\text { (Inactivated) }\end{array}$ & PBMC & $\begin{array}{l}\text { HumanHT- } \\
\text { 12_v4_2018 }\end{array}$ & $\begin{array}{c}\text { HumanHT- } \\
12 \_2018\end{array}$ & Illumina & $0,2,4,7,28$ & GSE59654 \\
\hline SDY520 & $\begin{array}{c}\text { Influenza } \\
\text { (Inactivated) }\end{array}$ & Whole blood & $\begin{array}{l}\text { HumanHT- } \\
\text { 12_v4_2018 }\end{array}$ & $\begin{array}{c}\text { HumanHT- } \\
12 \_2018\end{array}$ & Illumina & $0,2,7,28$ & GSE101709 \\
\hline
\end{tabular}




\begin{tabular}{|c|c|c|c|c|c|c|c|}
\hline SDY56 & $\begin{array}{c}\text { Influenza } \\
\text { (Inactivated) }\end{array}$ & PBMC & $\begin{array}{c}\text { HGU133_plus_ } \\
\text { PM }\end{array}$ & $\begin{array}{c}\text { HGU133_plus_ } \\
\text { PM }\end{array}$ & Affymetrix & $0,1,3,7,14$ & GSE74817 \\
\hline SDY61 & $\begin{array}{c}\text { Influenza } \\
\text { (Inactivated) }\end{array}$ & PBMC & hgu133plus2 & hgu 133plus2 & Affymetrix & $0,3,7$ & $\begin{array}{c}\text { GSE29617/GS } \\
\text { E29614 } \\
\end{array}$ \\
\hline SDY63 & $\begin{array}{c}\text { Influenza } \\
\text { (Inactivated) }\end{array}$ & PBMC & $\begin{array}{l}\text { HumanHT- } \\
\text { 12_v4_2018 }\end{array}$ & $\begin{array}{l}\text { HumanHT- } \\
12 \_2018\end{array}$ & Illumina & $0,4,7,28$ & GSE59635 \\
\hline SDY640 & $\begin{array}{c}\text { Influenza } \\
\text { (Inactivated) }\end{array}$ & Whole blood & $\begin{array}{l}\text { HumanHT- } \\
\text { 12_v4_2018 }\end{array}$ & $\begin{array}{l}\text { HumanHT- } \\
12 \_2018\end{array}$ & Illumina & $0,2,7,28$ & GSE101710 \\
\hline SDY80 & $\begin{array}{c}\text { Influenza } \\
\text { (Inactivated) }\end{array}$ & PBMC & $\begin{array}{l}\text { HuGene-1_0- } \\
\text { st-v1 }\end{array}$ & $\begin{array}{l}\text { HuGene-1_0- } \\
\text { st-v1 }\end{array}$ & Affymetrix & $-7,0,1,7,70$ & GSE47353 \\
\hline SDY269 & $\begin{array}{l}\text { Influenza (Live } \\
\text { attenuated) }\end{array}$ & PBMC & $\begin{array}{c}\text { HGU133_plus_ } \\
\text { PM }\end{array}$ & $\begin{array}{c}\text { HGU133_plus_ } \\
\text { PM }\end{array}$ & Affymetrix & $0,3,7$ & $\begin{array}{c}\text { GSE29615/GS } \\
\text { E29617/GSE29 } \\
614\end{array}$ \\
\hline SDY1293 & $\begin{array}{c}\text { Malaria } \\
\text { (Recombinant } \\
\text { protein) }\end{array}$ & PBMC & hgu133plus2 & hgu133plus2 & Affymetrix & $0,1,3,14$ & GSE18323 \\
\hline SDY1260 & $\begin{array}{l}\text { Meningococcus } \\
\text { (Conjugate) }\end{array}$ & PBMC & $\begin{array}{c}\text { HGU133_plus_ } \\
\text { PM }\end{array}$ & $\begin{array}{l}\text { HGU133_plus_ } \\
\text { PM }\end{array}$ & Affymetrix & $0,3,7$ & GSE52245 \\
\hline SDY1325 & $\begin{array}{l}\text { Meningococcus } \\
\text { (Conjugate) }\end{array}$ & Whole blood & $\begin{array}{l}\text { HumanHT- } \\
\text { 12_v4_2018 }\end{array}$ & $\begin{array}{l}\text { HumanHT- } \\
12 \_2018\end{array}$ & Illumina & 0,7 & GSE92884 \\
\hline SDY1260 & $\begin{array}{l}\text { Meningococcus } \\
\text { (Polysaccharid } \\
\text { e) }\end{array}$ & PBMC & $\begin{array}{c}\text { HGU133_plus_ } \\
\text { PM }\end{array}$ & $\begin{array}{l}\text { HGU133_plus_ } \\
\text { PM }\end{array}$ & Affymetrix & $0,3,7$ & GSE52245 \\
\hline SDY1325 & $\begin{array}{c}\text { Meningococcus } \\
\text { (Polysaccharid } \\
\text { e) }\end{array}$ & Whole blood & $\begin{array}{l}\text { HumanHT- } \\
\text { 12_v4_2018 }\end{array}$ & $\begin{array}{l}\text { HumanHT- } \\
\text { 12_2018 }\end{array}$ & Illumina & 0,7 & GSE92884 \\
\hline SDY180 & $\begin{array}{c}\text { Pneumococcus } \\
\text { (Polysaccharid } \\
\text { e) }\end{array}$ & Whole blood & $\begin{array}{l}\text { HumanHT- } \\
\text { 12_v3_2018 }\end{array}$ & $\begin{array}{l}\text { HumanHT- } \\
\text { 12_2018 }\end{array}$ & Illumina & $\begin{array}{c}- \\
7,0,0.5,1,3,7,10 \\
, 14,21,28 \\
\end{array}$ & GSE48762 \\
\hline SDY1370 & $\begin{array}{l}\text { Smallpox (Live } \\
\text { attenuated) }\end{array}$ & PBMC & $\begin{array}{l}\text { HEEBOHuman } \\
\text { SetV1_2019 }\end{array}$ & $\begin{array}{l}\text { HEEBOHuman } \\
\text { SetV1_2019 }\end{array}$ & $\begin{array}{c}\text { Stanford } \\
\text { Functional } \\
\text { Genomics } \\
\text { Facility }\end{array}$ & $0,3,7,10,13,21$ & GSE22121 \\
\hline SDY1370 & $\begin{array}{l}\text { Smallpox (Live } \\
\text { attenuated) }\end{array}$ & PBMC & $\begin{array}{l}\text { HEEBOHuman } \\
\text { SetV1_2019 }\end{array}$ & $\begin{array}{l}\text { HEEBOHuman } \\
\text { SetV1_2019 }\end{array}$ & $\begin{array}{c}\text { Stanford } \\
\text { Functional } \\
\text { Genomics }\end{array}$ & $0,3,7,10,13,21$ & GSE22121 \\
\hline
\end{tabular}




\begin{tabular}{|c|c|c|c|c|c|c|c|}
\hline & & & & & Facility & & \\
\hline SDY1364 & $\begin{array}{l}\text { Tuberculosis } \\
\text { (Recombinant } \\
\text { Viral Vector) }\end{array}$ & PBMC & $\begin{array}{l}\text { HumanHT- } \\
\text { 12_v4_2018 }\end{array}$ & $\begin{array}{l}\text { HumanHT- } \\
\text { 12_2018 }\end{array}$ & Illumina & $0,2,7$ & GSE40719 \\
\hline SDY984 & $\begin{array}{c}\text { Varicella } \\
\text { Zoster (Live } \\
\text { attenuated) }\end{array}$ & PBMC & $\begin{array}{c}\text { HGU133_plus_ } \\
\text { PM }\end{array}$ & $\begin{array}{l}\text { HGU133_plus_ } \\
\text { PM }\end{array}$ & Affymetrix & $0,1,3,7$ & GSE79396 \\
\hline SDY1264 & $\begin{array}{c}\text { Yellow Fever } \\
\text { (Live } \\
\text { attenuated) }\end{array}$ & PBMC & hgu133plus2 & hgu133plus2 & Affymetrix & $0,1,3,7,21$ & GSE13485 \\
\hline SDY1289 & $\begin{array}{c}\text { Yellow Fever } \\
\text { (Live } \\
\text { attenuated) }\end{array}$ & Whole blood & $\begin{array}{l}\text { IlluminaHuman } \\
\text { Ref8_v2 }\end{array}$ & $\begin{array}{l}\text { IlluminaHuman } \\
\text { Ref8_v2 }\end{array}$ & Illumina & $\begin{array}{c}0,3,7,10,14,28 \\
60\end{array}$ & GSE13699 \\
\hline SDY1294 & $\begin{array}{c}\text { Yellow Fever } \\
\text { (Live } \\
\text { attenuated) }\end{array}$ & PBMC & $\begin{array}{l}\text { AffyPrimeVie } \\
\text { w_2016 }\end{array}$ & $\begin{array}{c}\text { AffyPrimeVie } \\
\text { w_2016 }\end{array}$ & Affymetrix & $\begin{array}{c}0,0.166666666 \\
666667,1,2,3,5 \\
7,14,28\end{array}$ & GSE82152 \\
\hline SDY1529 & $\begin{array}{c}\text { Yellow Fever } \\
\text { (Live } \\
\text { attenuated) }\end{array}$ & Whole blood & $\begin{array}{l}\text { HumanHT- } \\
\text { 12_v4_2018 }\end{array}$ & $\begin{array}{l}\text { HumanHT- } \\
\text { 12_2018 }\end{array}$ & Illumina & $0,3,7,14,84$ & $\begin{array}{c}\text { GSE125921/G } \\
\text { SE136163 }\end{array}$ \\
\hline
\end{tabular}

9 
Table 3: Studies with corresponding Immune Response Data

\begin{tabular}{|c|c|c|c|c|}
\hline Study Accession & Pathogen Vaccine type & $\begin{array}{c}\text { Number of } \\
\text { Participants }\end{array}$ & Number of Samples & $\begin{array}{l}\text { Selected Immune } \\
\text { Response Assay }\end{array}$ \\
\hline SDY1328 & Hepatitis B (Inactivated) & 160 & 320 & ELISA \\
\hline SDY1119 & Influenza (Inactivated) & 72 & 177 & HAI \\
\hline SDY1276 & Influenza (Inactivated) & 214 & 816 & HAI, NAb \\
\hline SDY180 & Influenza (Inactivated) & 12 & 102 & $\mathrm{HAI}, \mathrm{NAb}$ \\
\hline SDY212 & Influenza (Inactivated) & 88 & 88 & HAI \\
\hline SDY224 & Influenza (Inactivated) & 5 & 55 & HAI \\
\hline SDY269 & Influenza (Inactivated) & 28 & 80 & HAI \\
\hline SDY270 & Influenza (Inactivated) & 28 & 83 & HAI \\
\hline SDY400 & Influenza (Inactivated) & 30 & 120 & HAI \\
\hline SDY404 & Influenza (Inactivated) & 39 & 156 & HAI \\
\hline SDY520 & Influenza (Inactivated) & 24 & 94 & HAI \\
\hline SDY56 & Influenza (Inactivated) & 30 & 148 & HAI \\
\hline SDY61 & Influenza (Inactivated) & 9 & 27 & HAI \\
\hline SDY63 & Influenza (Inactivated) & 19 & 72 & HAI \\
\hline SDY640 & Influenza (Inactivated) & 20 & 79 & HAI \\
\hline SDY67 & Influenza (Inactivated) & 159 & 477 & HAI \\
\hline SDY80 & Influenza (Inactivated) & 60 & 281 & $\mathrm{NAb}$ \\
\hline SDY269 & Influenza (Live attenuated) & 28 & 83 & HAI \\
\hline SDY1260 & Meningococcus (Conjugate) & 17 & 51 & ELISA \\
\hline SDY1325 & Meningococcus (Conjugate) & 4 & 8 & $\mathrm{NAb}$ \\
\hline SDY1260 & Meningococcus (Polysaccharide) & 13 & 39 & ELISA \\
\hline SDY1325 & Meningococcus (Polysaccharide) & 5 & 10 & $\mathrm{NAb}$ \\
\hline SDY180 & Pneumococcus (Polysaccharide) & 6 & 54 & $\mathrm{NAb}$ \\
\hline SDY1370 & Smallpox (Live attenuated) & 4 & 24 & ELISA \\
\hline SDY1370 & Smallpox (Live attenuated) & 4 & 24 & ELISA \\
\hline SDY1364 & Tuberculosis (Recombinant Viral Vector) & 12 & 36 & ELISA \\
\hline SDY984 & Varicella Zoster (Live attenuated) & 35 & 140 & ELISA \\
\hline SDY1264 & Yellow Fever (Live attenuated) & 25 & 87 & $\mathrm{NAb}$ \\
\hline SDY1289 & Yellow Fever (Live attenuated) & 14 & 84 & $\mathrm{NAb}$ \\
\hline SDY1294 & Yellow Fever (Live attenuated) & 21 & 109 & $\mathrm{NAb}$ \\
\hline SDY1529 & Yellow Fever (Live attenuated) & 36 & 180 & $\mathrm{NAb}$ \\
\hline
\end{tabular}




\begin{tabular}{|c|c|}
\hline File name & Description \\
\hline all_noNorm_eset.rds & Gene expression matrix of all participants, $\log 2$-normalized expression \\
\hline all_noNorm_withResponse_eset.rds & $\begin{array}{l}\text { Gene expression matrix of all participants with matched immune response } \\
\text { data, log2-normalized expression }\end{array}$ \\
\hline all_norm_eset.rds & $\begin{array}{l}\text { Gene expression matrix of all participants that are cross-study normalized } \\
\text { and batch corrected }\end{array}$ \\
\hline all_norm_withResponse_eset.rds & $\begin{array}{l}\text { Gene expression matrix of all participants with matched simmune } \\
\text { response dataset, cross-study normalized and batch corrected }\end{array}$ \\
\hline young_noNorm_eset.rds & Gene expression matrix of participants aged $18-50, \log 2$-normalized \\
\hline young_noNorm_withResponse_eset.rds & $\begin{array}{l}\text { Gene expression matrix of participants aged } 18-50 \text { with matched immune } \\
\text { response data, log2-normalized }\end{array}$ \\
\hline young_norm_eset.rds & $\begin{array}{l}\text { Gene expression matrix of participants aged } 18-50, \text { cross-study } \\
\text { normalized and batch corrected }\end{array}$ \\
\hline young_norm_withResponse_eset.rds & $\begin{array}{l}\text { Gene expression matrix of participants aged } 18-50 \text { with matched immune } \\
\text { response data, cross-study normalized and batch corrected }\end{array}$ \\
\hline old_noNorm_eset.rds & Gene expression matrix of participants aged $60-90, \log 2$-normalized \\
\hline old_noNorm_withResponse_eset.rds & $\begin{array}{c}\text { Gene expression matrix of participants aged } 60-90 \text { with matched immune } \\
\text { response data, log2-normalized expression }\end{array}$ \\
\hline old_norm_batchCorrectedFromYoung_eset.rds & $\begin{array}{c}\text { Gene expression matrix of participants aged 60-90, cross-study } \\
\text { normalized and batch corrected using age correction coefficients from } \\
\text { young }\end{array}$ \\
\hline old_norm_batchCorrectedFromYoung_withResponse_eset.rds & $\begin{array}{l}\text { Gene expression matrix of participants aged } 60-90 \text { with matched immune } \\
\text { response data, cross-study normalized and batch corrected using age } \\
\text { correction coefficients from young }\end{array}$ \\
\hline extendedOld_noNorm_eset.rds & $\begin{array}{c}\text { Gene expression matrix of participants aged 50-90, } \log 2 \text {-normalized } \\
\text { expression }\end{array}$ \\
\hline extendedOld_noNorm_withResponse_eset.rds & $\begin{array}{c}\text { Gene expression matrix of participants aged 50-90 with matched immune } \\
\text { response data, log2-normalized counts }\end{array}$ \\
\hline
\end{tabular}




\begin{tabular}{|c|c|}
\hline extendedOld_norm_batchCorrectedFromYoung_eset.rds & Gene expression matrix of participants aged 50-90, log2-normalized \\
expression
\end{tabular}

